\title{
44. CALCAREOUS NANNOFOSSILS ACROSS THE CRETACEOUS/TERTIARY BOUNDARY, SITE 761, NORTHWEST AUSTRALIAN MARGIN ${ }^{1}$
}

\author{
James J. Pospichal ${ }^{2}$ and Timothy J. Bralower ${ }^{3}$
}

\begin{abstract}
A biostratigraphically complete (all nannofossil biozones present) Cretaceous/Tertiary boundary was recovered at Site 761 on the Wombat Plateau, northwest Australian margin, during Ocean Drilling Program Leg 122. A quantitative study of calcareous nannofossils on closely spaced samples across the boundary reveals a rapid change in assemblages in a similar fashion to other Cretaceous/Tertiary boundary sites. Nannofossil species were placed into three categories: Tertiary, Cretaceous, and "survivors." The rapid sequential turnover in these assemblages is as follows: Cretaceous species are abruptly replaced at the boundary by opportunistic survivor species, which in turn are abruptly replaced by newly evolved Tertiary taxa. The uppermost Maestrichtian assemblage is distinctly mid-latitudinal with few Micula murus and rare to few Nephrolithus frequens. The nannofossil assemblage immediately above the boundary is dominated by an abundance bloom of Cyclagelosphaera spp. No Thoracosphaera or Braarudosphaera abundance blooms are present as at many other localities.

The change from a survivor- to Tertiary-dominated assemblage is coincident with the CP1a/CP1b nannofossil subzonal boundary, which is marked by the simultaneous first occurrence of several species including Cruciplacolithus tenuis and $C$. primus. The latter is found to first occur below $C$. tenuis in the most complete Cretaceous/Tertiary sections. A hiatus between Subzones CP1a and CP1b is interpreted to explain this discrepancy.
\end{abstract}

\section{INTRODUCTION}

Six sites (759-764) were drilled on the Exmouth and Wombat plateaus of the northwestern Australian margin during Ocean Drilling Program (ODP) Leg 122 (Fig. 1). The immediate objectives for coring a transect along Exmouth Plateau and the Argo Abyssal Plain (Leg 123) were: (1) to compare tectonic and seismic sequences with Atlantic passive continental margins, (2) to help refine the Mesozoic geological time scale, and (3) to characterize old ocean crust prior to subduction under the Sundra arc (Haq, von Rad, O'Connell, et al., 1990).

This study focuses on the Cretaceous/Tertiary $(\mathrm{K} / \mathrm{T})$ boundary recovered in Hole $761 \mathrm{C}$ on the Wombat Plateau $\left(16^{\circ} 44.23^{\prime} \mathrm{S}, 115^{\circ} 32.10^{\prime} \mathrm{E}\right)$ at a water depth of $2167.9 \mathrm{~m}$. The approximate location of this site and other Indian Ocean boundary sites at $66 \mathrm{Ma}$ is shown in Figure 2. Site 761 is interpreted to have moved to its present position from about $30^{\circ}$ or higher at $\mathrm{K} / \mathrm{T}$ boundary time.

The boundary section consists of dark greenish gray Danian nannofossil chalk overlying uppermost Maestrichtian white nannofossil chalk (Figs. 3 and 4A, -B). The lowermost Danian nannofossil biozone, CP1a, is only $16 \mathrm{~cm}$ thick, which is thin compared to other deep-sea sequences such as at Site 752 (southern Indian Ocean) where it is up to $6 \mathrm{~m}$ thick (Pospichal, 1991). This may imply either much lower sedimentation rates at this site or a brief hiatus.

This is the third in a series of related papers that concern the quantitative analysis of calcareous nannofossil assemblages across the Cretaceous/Tertiary boundary in ODP cores (Pospichal and Wise, 1990; Pospichal, 1991). The following is

\footnotetext{
1 von Rad, U., Haq, B. U., et al., 1992. Proc. ODP, Sci. Results, 122: College Station, TX (Ocean Drilling Program).

2 Department of Geology, Florida State University, Tallahassee, FL 323063026, U.S.A.

${ }^{3}$ Department of Geology, Florida International University, Miami, FL 33199, U.S.A. (Current address: Department of Geology, University of North Carolina, Chapel Hill, NC 27599, U.S.A.)
}

a brief description of the nannofossil assemblage turnover of the biostratigraphically complete, but condensed, section recovered in Core $122-761 \mathrm{C}-3 \mathrm{R}$. In addition, comparisons are made with other recently cored Cretaceous/Tertiary boundaries of the Indian Ocean from Legs 119, 120, and 121 (Fig. 2). For further background on calcareous nannofossil biostratigraphy and assemblages of the Cretaceous/Tertiary boundary interval, the reader is referred to the summaries of Thierstein (1981) and Perch-Nielsen et al. (1982). Siesser and Bralower (this volume) provide the calcareous nannofossil biostratigraphy for the Cenozoic of Site 761 and Bralower and Siesser (this volume) do the same for the Mesozoic.

\section{METHODS}

Aboard ship, toothpick samples were taken at 1-cm increments across the boundary interval and at successively longer intervals through the entire $150 \mathrm{~cm}$ of Section 122-761C-3R-3 (Fig. 4B). Samples were carefully selected to avoid obvious burrows or sediment disturbed by drilling. Smear slides of raw sediment were analyzed under the light microscope at $1560 \times$, and at least 500 specimens per sample were counted. This number is chosen to ensure that infrequent taxa were included. Most samples were examined beyond this count, however, to uncover any additional species present and to assure that no biostratigraphic information was lost. In Sample $122-761 \mathrm{C}-3 \mathrm{R}-3,51 \mathrm{~cm}$, the total of 500 was reached within two fields of view because of the high abundance of Prinsius dimorphosus. In such cases, the count was extended beyond 500 to include a minimum of three fields of view.

The procedure for identifying and counting broken or partial specimens is similar to that described by Jiang and Gartner (1986). Fragments of specimens are counted only if they can be recognized at the species level. In addition, coccospheres are counted as one specimen. The calcareous dinoflagellate Thoracosphaera is most often found as broken pieces. For this genus, fragments larger than about onequarter to one-third of a whole specimen are counted and added up to one. Three of these fragments are considered to constitute one specimen as given in tabulations and plots. 


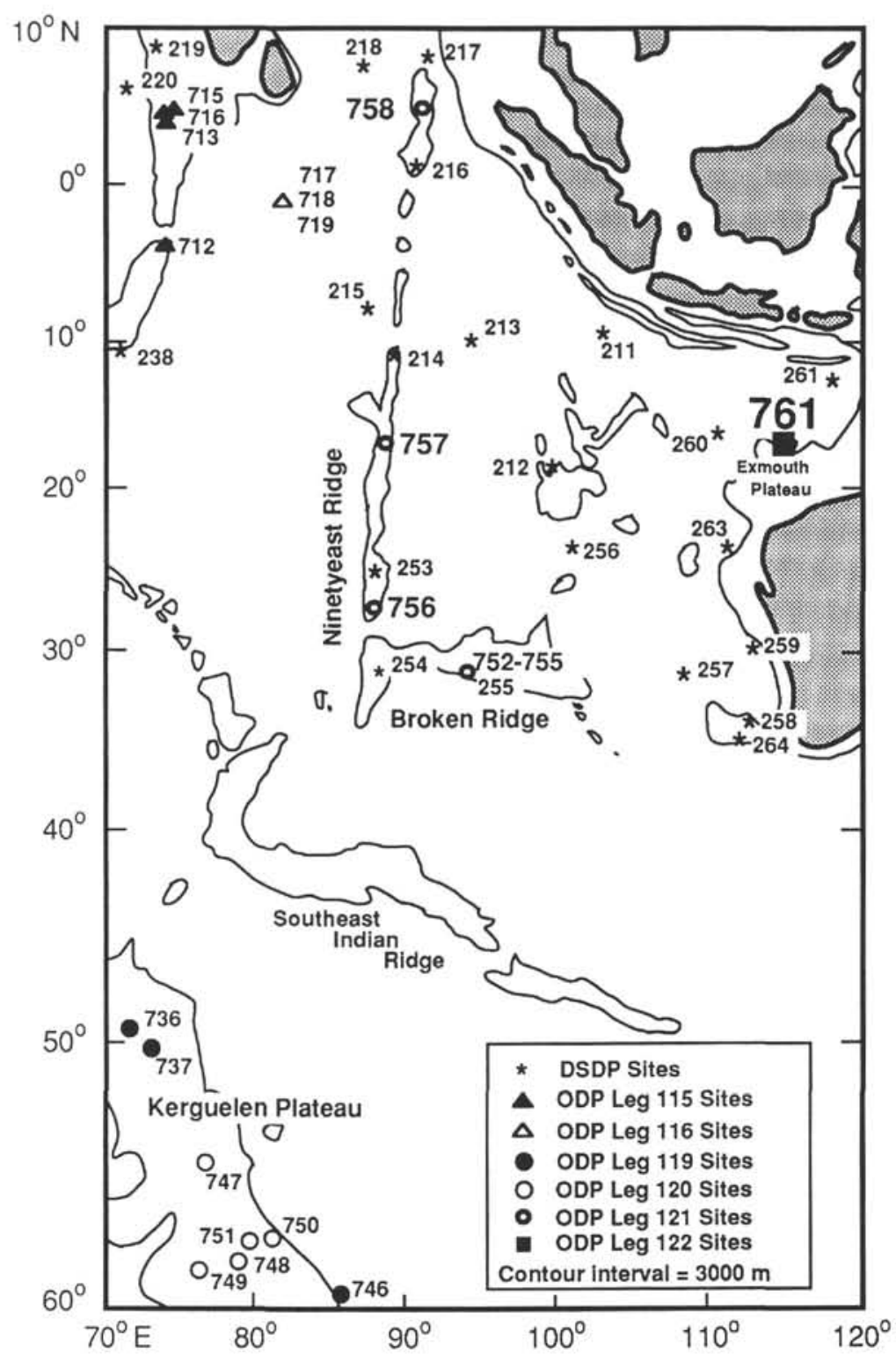

Figure 1. Location map of Leg 122 Site 761 (Exmouth Plateau) and other Indian Ocean ODP and DSDP sites referred to in this chapter.

For this study, the following forms were combined to facilitate counting: species of Thoracosphaera; Neocrepidolithus neocrassus and $N$. cruciatus; Coccolithus pelagicus and C. cavus; Cyclagelosphaera reinhardtii and $C$. alta; Arkhangelskiella cymbiformis and A. specillata; and species of $C y$ lindralithus.

The Cruciplacolithus species are differentiated here mainly by size. Small $C$. primus are those forms $5 \mu \mathrm{m}$ or less which have a very narrow outer rim. Large $C$. primus have a more robust rim and basically are morphologically the same as $C$. tenuis, except smaller (less than $7 \mu \mathrm{m}$ ). Specimens larger than $7 \mu \mathrm{m}$ are assigned to Cruciplacolithus tenuis. Cruciplacolithus edwardsii, a species with a slightly rotated central cross, is combined with $C$. tenuis. This species is rare in this section.

We have carried out an error analysis on the data obtained from assemblage studies in order to analyze whether variations observed between samples, based on a limited number of specimens counted, are real or whether they result from random variability. We have utilized the tables of Mainland et al. (1956) to calculate the confidence limits for percentages based on the binomial distribution at the 95th percent interval of confidence given a sample size of 500 . The lower the percentage, or the smaller the number of specimens counted, the more likely are the variations to be a result of random noise than real fluctuations in original nannofloral populations. This error analysis allows us to analyze whether a count of 500 specimens is sufficient to interpret the fluctuations observed and which of the changes observed are real.

\section{CRETACEOUS/TERTIARY BOUNDARY AT SITE 761}

\section{Lithostratigraphy}

The complete core descriptions for Holes $761 \mathrm{~B}$ and $761 \mathrm{C}$ are given in Haq, von Rad, O'Connell, et al. (1990) and summarized here in Figure 3. The Cretaceous/Tertiary boundary of Hole 761B, cored using the extended core barrel, corresponds to a sharp drilling contact and color change 


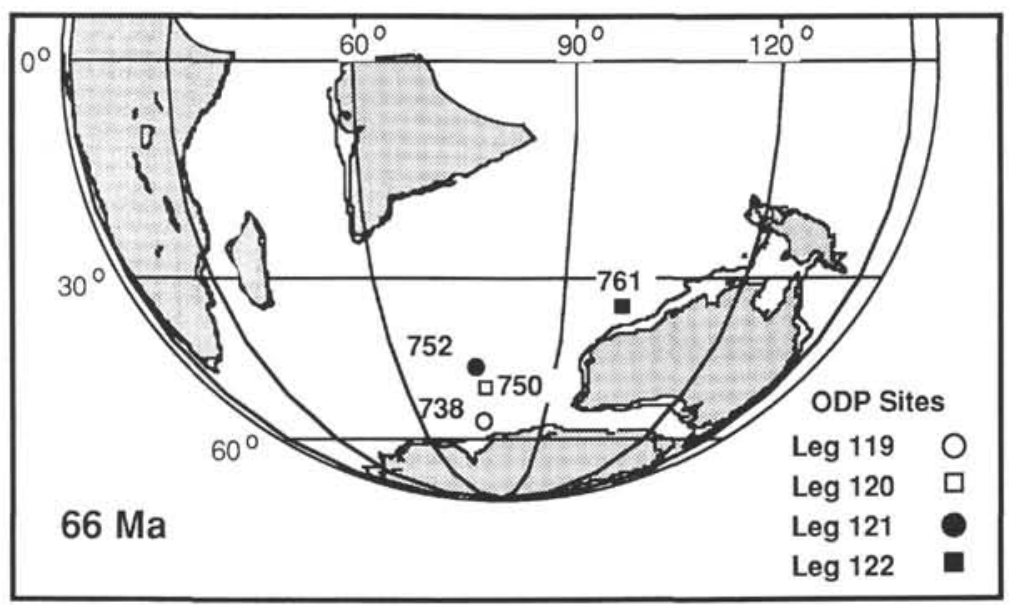

Figure 2. Tectonic reconstruction of the Indian Ocean for $66 \mathrm{Ma}$ (Scotese and Denham, Terra Mobilis ${ }^{\mathrm{TM}}$ ) with approximate locations of Leg 119 Site 738, Leg 120 Site 750, Leg 121 Site 752, and Leg 122 Site 761.

between Paleocene and Maestrichtian sediments, and is not complete. Hole $761 \mathrm{C}$ was rotary cored and the section here appears more complete, although the Cretaceous/Tertiary boundary core is slightly disturbed. The Cretaceous/Tertiary boundary of Hole $761 \mathrm{C}$ is located in Section 122-761C-3R-3 between 66 and $68 \mathrm{~cm}$ (Fig. 4A, -B). This is roughly $8 \mathrm{~cm}$ above the lithologic boundary between Subunit 1D and Subunit 11A of Haq, von Rad, O'Connell, et al. (1990) (Fig. 3). Subunit 1D of Paleocene age is described as massive nannofossil chalk with foraminifers, variably structureless or bioturbated and mottled. The lowest Paleocene strata is a mottled and bioturbated clay-rich nannofossil chalk with foraminifers and is dark greenish gray turning to light greenish gray $16 \mathrm{~cm}$ above the boundary. The lower Paleocene is separated from the underlying upper Maestrichtian by a drilling contact at 67 cm (Fig. 4B). Below the boundary, the topmost Maestrichtian is a bioturbated pale brown chalk about $8 \mathrm{~cm}$ thick. A sharp color change occurs at the base of this $8-\mathrm{cm}$ interval that marks the boundary between Subunit 1D and Subunit 11A. This underlying unit consists of white nannofossil chalk with foraminifers and with grayish brown chert nodules at the top (Fig. 4B).

The most obvious contact in Section 122-761C-3R-3 is between the upper Maestrichtian white chalk and the uppermost Maestrichtian pale brown chalk at $76 \mathrm{~cm}$ (Fig. 4B). One might perhaps consider this the actual Cretaceous/Tertiary contact; however, as discussed in the following section, the nannofossil assemblage change suggests that the boundary is between 66 and $68 \mathrm{~cm}$ where a less noticeable color change occurs. The $8 \mathrm{~cm}$ of pale brown uppermost Maestrichtian chalk is probably a bioturbated mixture of lower Paleocene and upper Maestrichtian material (Fig. 4B). This idea is supported by a subtle increase in the percentage of survivor nannofossils in this interval but not as abrupt a change as occurs between 66 and $68 \mathrm{~cm}$. Also, an obvious change occurs in the abundance of micrite particles and clay between these two samples. At $66 \mathrm{~cm}$, the percentage of clay and silt-sized disseminated carbonate debris increases sharply while the bulk percentage of nannofossils decreases from about $40 \%$ to $10 \%$ of the total sediment. This is coincident with a noticeable change in the nannofossil assemblage and is the most likely horizon at which to place the boundary.

A distinct "boundary clay" as noted at many other $\mathrm{K} / \mathrm{T}$ boundary localities is not present in this section, although the amount of clay does increase coincident with the color change at the boundary level. An unconformity may explain the absence of a "boundary clay" or this level may have been smeared out by bioturbation as suggested by the abundance of burrows in the boundary interval. The contact at $76 \mathrm{~cm}$ in Core $122-761$ C-3R-3 is sharp and uneven (Fig. 4B), which probably indicates the presence of an unconformity at least at this level.

\section{Magnetostratigraphy and Chemostratigraphy}

The Cretaceous/Tertiary boundary of Hole $761 \mathrm{C}$ lies within an interval of reversed polarity assigned to Chron 29R (Rocchia et al., this volume), the chron with which it is correlated in all boundary sections considered complete. These authors also note a peak abundance of iridium in Sample 122-761C-3R-3, 75-76 $\mathrm{cm}$, which coincides with a change in sediment color from pale white to light brown (Fig. 4B). This level is $8 \mathrm{~cm}$ below the level at which we have placed the nannofossil boundary $(67 \mathrm{~cm})$ based on the most distinct shift in nannofossil assemblages. This disparity may suggest that the origin of elevated abundance peaks of iridium and nannofossil assemblage changes may not be causally related. However, considering factors such as bioturbation, which can smear out any direct signal in such a short interval $(8 \mathrm{~cm})$, a causal relationship, or lack thereof in this case, may not be easily proven.

\section{CALCAREOUS NANNOFOSSILS}

Individually counted calcareous nannofossil specimens were placed in one of three categories: Cretaceous, Tertiary, or "survivor." Tertiary forms are those which appear at or above the boundary and Cretaceous forms become extinct at or below the boundary. Survivor species are those which are present in the Cretaceous and cross the boundary or have direct descendants that survive into the Tertiary. The procedure is similar to that used by Thierstein and Okada (1979) at Deep Sea Drilling Project (DSDP) Site 384 and Percival and Fischer (1977) at the Zumaya section in Spain (see Pospichal and Wise, 1990; Pospichal, 1991). The definitions of these assemblages are similar to those of Perch-Nielsen et al. (1982).

The percentages of these three groups were calculated and plotted in Figure 5 and listed in Table 1. Individual abundance counts are included in Table 1 with percentage abundances of selected taxa plotted in Figure 6. All nannofossil species referred to in this report are cited in the Appendix. 


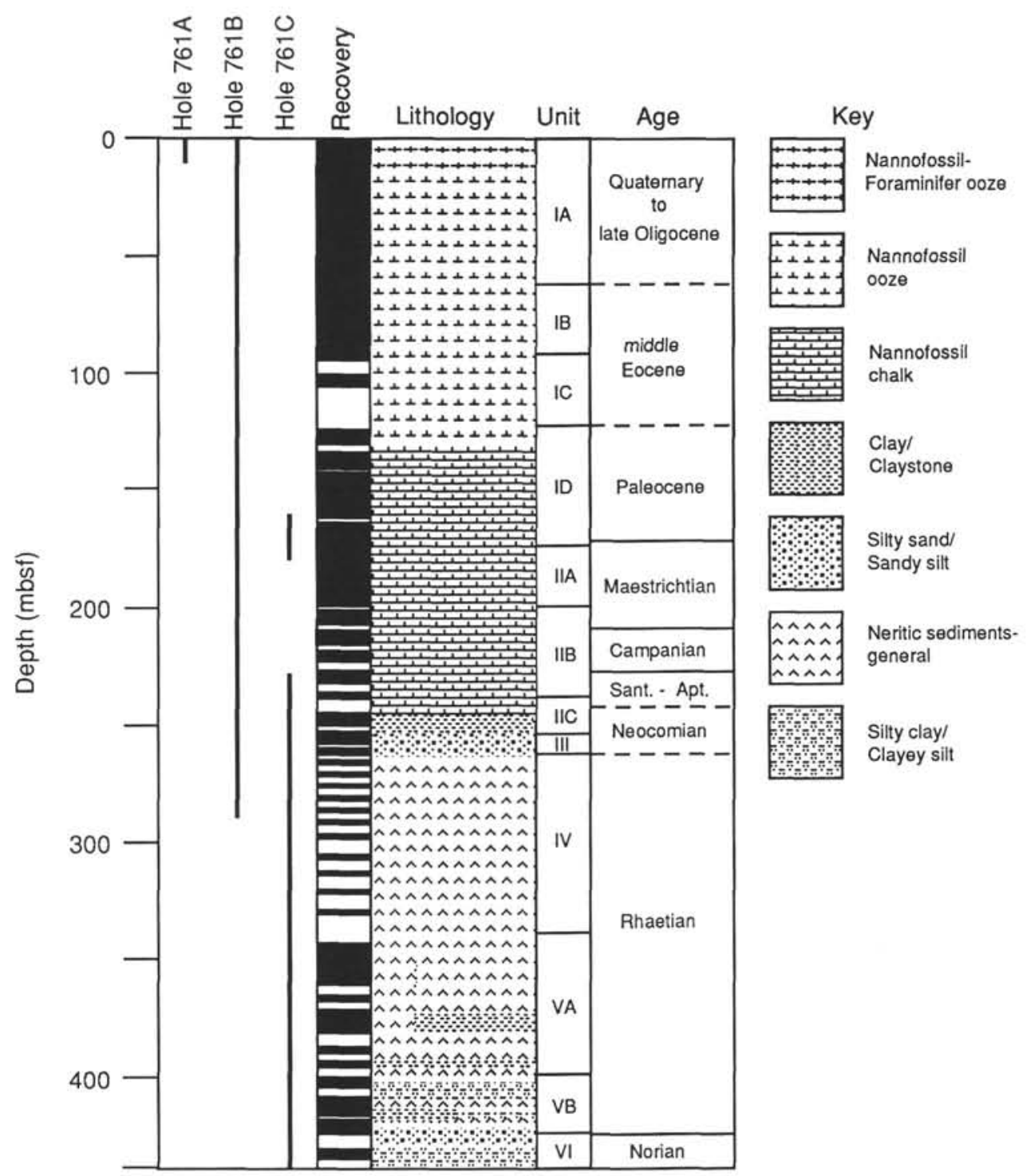

Figure 3. Lithologic columns for Holes $761 \mathrm{~B}$ and $761 \mathrm{C}$. Shaded region represents percentage recovery for each core.

In the Cretaceous samples examined, calcareous nannofossils are abundant and moderately well preserved. Some forms exhibit overgrowth; however, dissolution is minor, so assemblage bias due to poor preservation is considered minimal. The percentage of nannofossils in the bulk sediment decreases in the samples of Subzone CPla above the boundary coincident with an increase in clay-sized disseminated carbonate. Dissolution is more pervasive in this interval, which may bias the sample toward more robust forms. The abundance of nannofossils increases sharply above the Subzone CP1a/CP1b $(51 \mathrm{~cm})$ boundary, which is separated by a hiatus as discussed later. Preservation in the samples of Subzone CP1b is moderate.

Cretaceous forms comprise between $95 \%$ and $99 \%$ of the assemblage in the samples from $148 \mathrm{~cm}$ to $73 \mathrm{~cm}$ (Fig. 5). Below the boundary, where the change from white to pale brown chalk occurs, the percentage of survivor forms increases from $5 \%$ to $15 \%$ between 73 and $70 \mathrm{~cm}$ (Figs. 4, 5). The increase in survivor forms in this interval may be readily explained as the result of natural mixing by bioturbation and indeed these sediments are burrowed (Fig. 4B).
At $67 \mathrm{~cm}$, survivor forms constitute $24 \%$ of the assemblage, which is still dominated by Cretaceous taxa. Above the boundary, at $66 \mathrm{~cm}$, survivors rapidly increase to $67 \%$ of the assemblage and Tertiary forms first occur and remain rare throughout Subzone CP1a. The survivors dominate the total assemblage in the samples of Subzone CPla. Cretaceous taxa comprise about $25 \%$ to $30 \%$ of the assemblage in this interval $(66-53 \mathrm{~cm})$. In samples from 51 to $15 \mathrm{~cm}$, Tertiary taxa constitute about $90 \%$ to $95 \%$ of the assemblage. Cretaceous species drop off rapidly and comprise about $1 \%$ or less in this interval. The nannofossil assemblage transition from Subzones CP1a to CP1b between $53 \mathrm{~cm}$ and $51 \mathrm{~cm}$ is characterized by an abrupt influx and dominance of Tertiary species. The topmost samples analyzed, at $10 \mathrm{~cm}$ and $13 \mathrm{~cm}$, record an interval of intense reworking. These samples, which lie above an erosional contact between 13 and $15 \mathrm{~cm}$, contain about $50 \%$ Cretaceous forms and $50 \%$ survivors, with only a few Tertiary forms present (Fig. 5, Table 1).

The following sections contain brief descriptions and discussions of the individual constituents of the three assemblages discussed. Some comparisons are made with other 

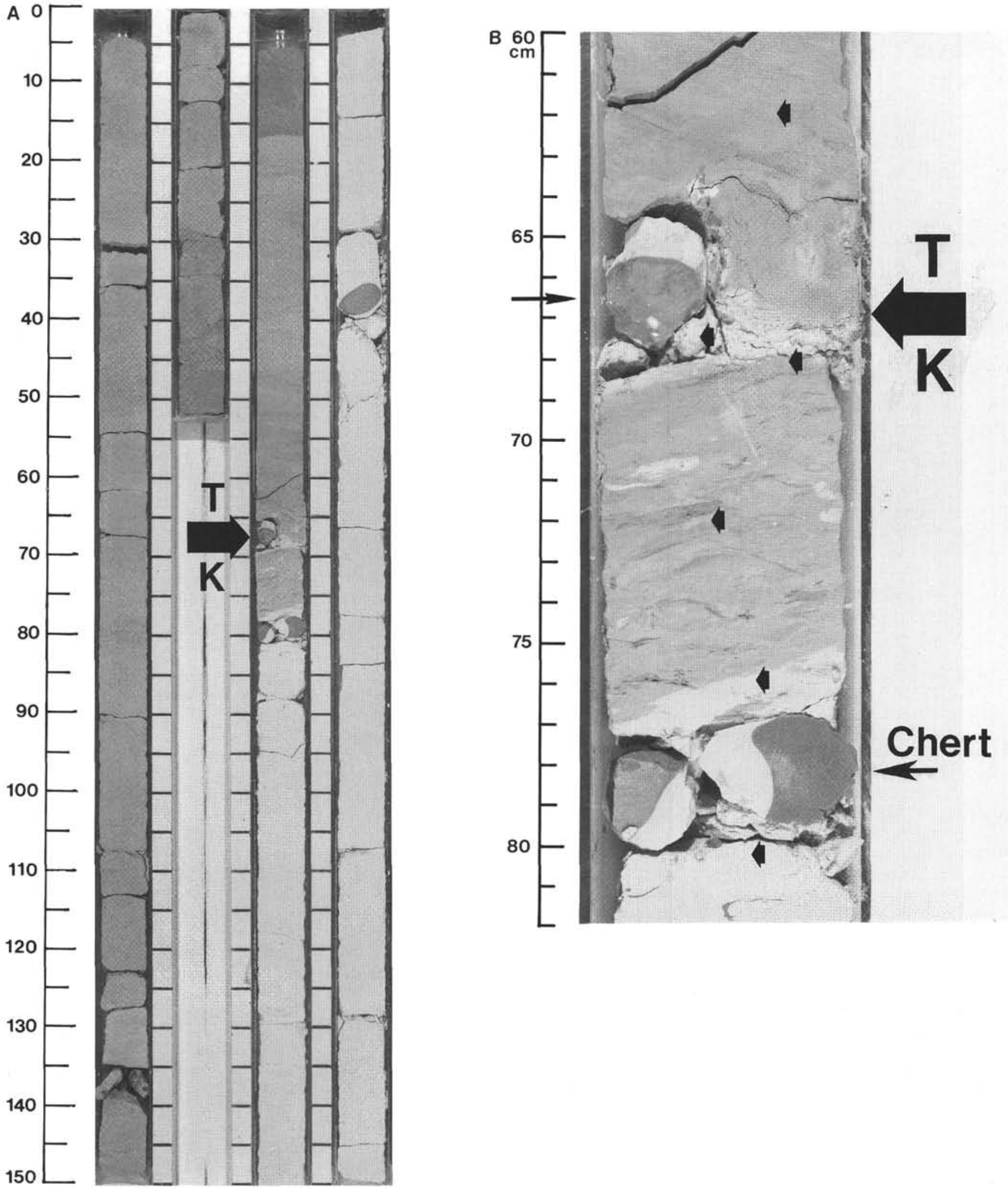

Figure 4. A. Core 122-761C-3R. The Cretaceous/Tertiary boundary is located in Section 122-761C-3R-3 at $67 \mathrm{~cm}$, as shown by an arrow. B. Enlargement of Cretaceous/Tertiary boundary interval. Drilling contact and Cretaceous/Tertiary boundary is shown by a large arrow. Sediment above $68 \mathrm{~cm}$ is Danian, dark greenish gray nannofossil chalk. The interval from $68 \mathrm{~cm}$ to $76 \mathrm{~cm}$ is bioturbated, light brownish gray overlying Maestrichtian white chalk. Chert nodules are indicated by medium-sized arrows. Small arrows denote sample locations. (Note: Because of sediment movement within the core liner, sample locations in this photo differ from original sample designations by approximately $1 \mathrm{~cm}$. For example, as shown in this figure, the sample at $76 \mathrm{~cm}$ actually corresponds to Sample $122-761 \mathrm{C}-3 \mathrm{R}-3,75 \mathrm{~cm}$, as given in the text and in Table 1.) 


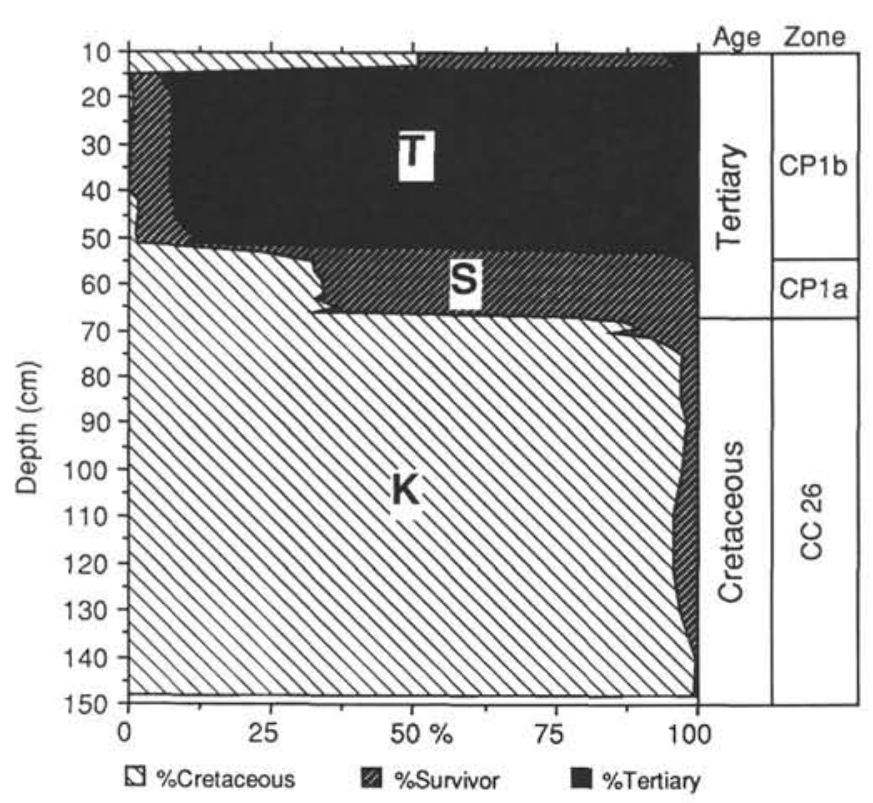

Figure 5. Percentage abundance of Cretaceous vs. Tertiary vs. "survivor" nannofossil species across the Cretaceous/Tertiary boundary in Section 122-761C-3R-3, 10-150 cm, with nannofossil stratigraphy.

Cretaceous/Tertiary boundary localities around the globe and especially with recently recovered sections in the Indian Ocean (Fig. 2).

\section{Cretaceous}

The diversity of the uppermost Maestrichtian assemblage stands at about 35 taxa. Preservation is moderate with slight overgrowth on some forms such as Micula decussata. Bias towards dissolution-resistant forms is probably minimal in this assemblage. Species distribution is fairly even in samples from 68 to $148 \mathrm{~cm}$ of Section 122-761C-3R-3. The most dominant species are Prediscosphaera cretacea and Micula decussata, which comprise between $15 \%$ to $20 \%$ of the assemblage and Watznaueria barnesae at $10 \%$ to $15 \%$ (Fig. 6, Table 1). Arkhangelskiella cymbiformis, Cribrosphaerella ehrenbergii, Cretarhabdus conicus, Lithraphidites quadratus, and Prediscosphaera stoveri constitute the bulk of the remaining assemblage.

The Cretaceous assemblage in Hole $761 \mathrm{C}$ appears to be more typical of low to mid-latitudes based on the compilation of Thierstein (1981). The lack of common $M$. murus and the absence of $M$. prinsii may be more indicative of a mid-latitude range than a factor of preservation or stratigraphy. In conjunction with this, the presence of rare to few Nephrolithus frequens, Kamptnerius magnificus, and Cribrosphaerella daniae, and common Prediscosphaera stoveri, also demonstrates the mid-latitude nature of the Cretaceous assemblage.

These species are well-documented high-latitude forms except for $P$. stoveri, whose abundance distribution has only recently been studied in austral latitude sites. This species or one very similar ( $P$. quadripunctata) was noted by Jiang and Gartner (1986) to show an increase in abundance from $3 \%$ up to $15 \%$ of the assemblage at the very top of the Maestrichtian in sections from Brazos River, Texas, and El Kef, Tunisia. Pospichal and Wise (1990) noted a complete dominance by $P$. stoveri of about $65 \%$ of the assemblage in sediments directly below the Cretaceous/Tertiary boundary at the extreme high-latitude Site $690\left(65^{\circ} \mathrm{S}\right)$ in the Weddell Sea. This species is also quite abundant below the boundary at other high-latitude sites, including Site $738\left(63^{\circ} \mathrm{S}\right)$ (Wei and Thierstein, 1991) and at Site $750\left(57^{\circ} \mathrm{S}\right)$ (Watkins, in press). At Site 752 , the peak abundance of this form is about $30 \%$, and its overall abundance is less than at the more southerly localities (Pospichal, 1991).

It is clear that the abundance of $P$. stoveri in uppermost Maestrichtian sediments increases with latitude in the Southern Hemisphere and that its peak abundance occurs just below the boundary. In the present study, $P$. stoveri reaches a peak abundance of only about $8 \%$ in samples just below the boundary at 68 and $71 \mathrm{~cm}$. This percentage is much lower than that recorded in the higher latitude Indian Ocean localities but is rather similar to what Jiang and Gartner (1986) noted in the lower latitude sections of Brazos River and El Kef. The lack of an interval containing notably higher percentages of $P$. stoveri or percentages similar to nearby Site 752 could reflect the provinciality of this event or, alternatively, indicate that the topmost Maestrichtian is absent. The latter possibility could also explain the absence of Micula prinsii (see section on "Biostratigraphy").

\section{Survivors}

Survivor species are those which appear in the Cretaceous and survive into the Tertiary or have direct descendants which survive into the Tertiary (Perch-Nielsen et al., 1982). These are the "persistent" species of Percival and Fischer (1977) and Jiang and Gartner (1986). These forms are generally rare to absent in Maestrichtian sediments but may become abundant and in many cases bloom in the wake of outgoing Cretaceous species (Thierstein, 1981). Most forms are generally noted to be more common in the Danian of higher northern and southern latitudes with the exception of Braarudosphaera and the calcareous dinoflagellate, Thoracosphaera, which are only known to show abundance blooms at several mid- to lower latitude sites (Percival and Fischer, 1977; Perch-Nielsen et al., 1982; Jiang and Gartner, 1986). In addition, Perch-Nielsen (1979a) noted that Thoracosphaera, while present in the Maestrichtian of many areas, only appears at or above the $\mathrm{K} / \mathrm{T}$ boundary in the mid to higher latitudes.

In this section the survivor assemblage includes Cyclagelosphaera reinhardtii, $C$. alta, Zygodiscus sigmoides, Markalius inversus, Biscutum castrorum (B. constans or oval morphotype of $M$. inversus of some authors), Thoracosphaera, Neocrepidolithus cruciatus, $N$. neocrassus, $N$. fossus, and Lapideacassis sp. (Table 1). The most abundant taxon in the $16-\mathrm{cm}$ interval of Subzone CP1a dominated by survivors is Cyclagelosphaera reinhardtii. This species, along with $C$. alta, constitutes nearly $40 \%$ of the assemblage in the sample immediately above the boundary at $66 \mathrm{~cm}$ before decreasing to about $20 \%$ to $30 \%$ within Subzone CP1a (Fig. 6, Table 1). Also, in the $3 \mathrm{~cm}$ above the boundary, Markalius inversus peaks in abundance at about $12 \%$ but is replaced above this as the second most abundant form by $Z$. sigmoides (Fig. 6, Table 1). This species reaches abundances of about $20 \%$ within Subzone CPla and is the most abundant survivor species in Subzone CP1b. Biscutum castrorum is slightly less abundant than $M$. inversus. The survivor species mentioned thus far are all found as minor $(<1 \%)$ components of the Maestrichtian sediments below (Fig. 6, Table 1). Species of Neocrepidolithus and Thoracosphaera constitute a minor portion of the assemblage of Subzone CP1a and only a few specimens of Lapideacassis sp. were noted at 53 and $65 \mathrm{~cm}$.

High abundances of Cyclagelosphaera are known from several outcrop localities. Thierstein (1981) reported a peak abundance of nearly $30 \%$ in the section at Braggs, Alabama, 
Table 1. Abundance counts of calcareous nannofossils in Section 122-761C-3R-3, 10-48 cm.

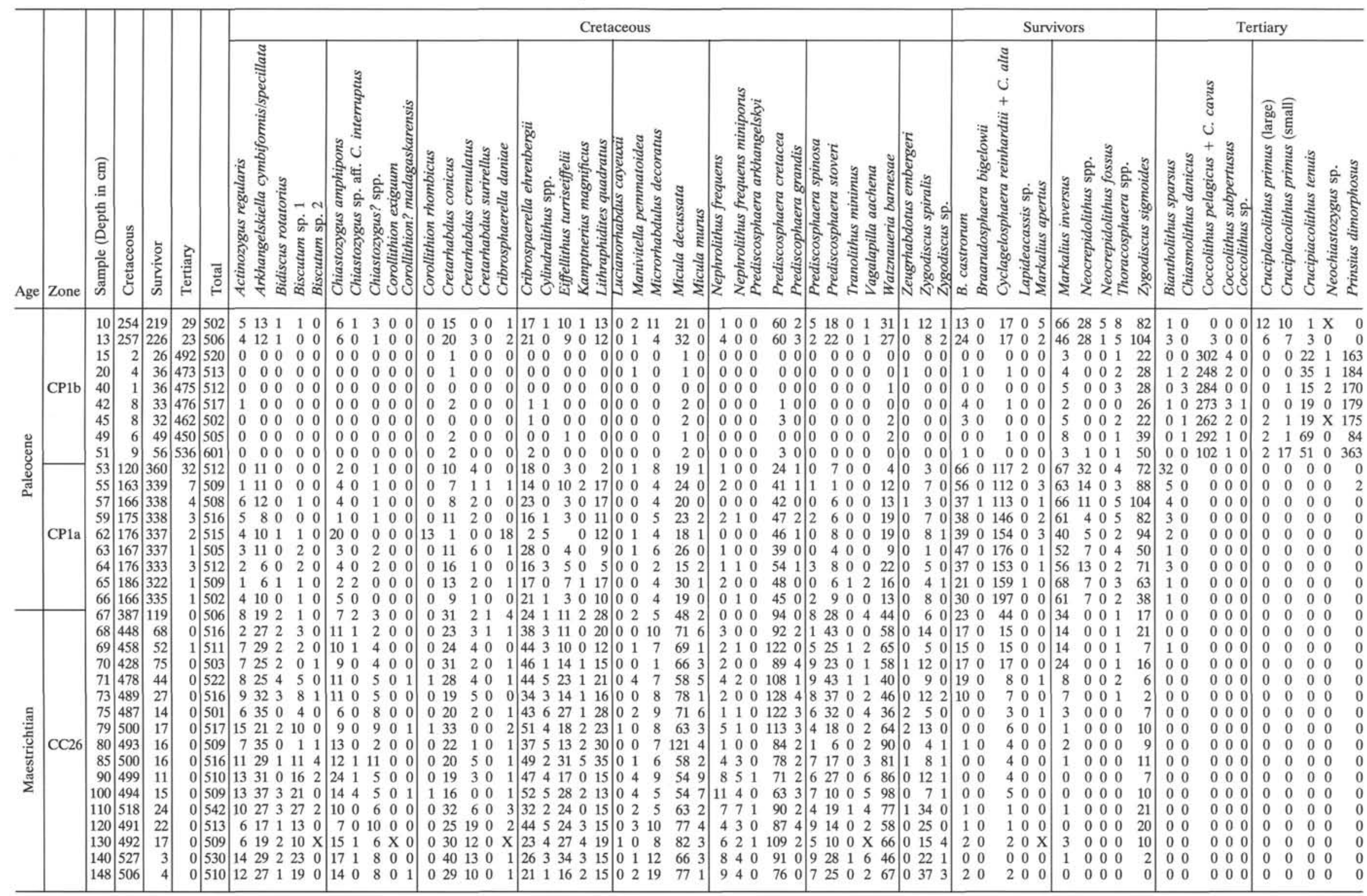

Note: " $\mathrm{X}$ " denotes species present but not included in count of 500 . 


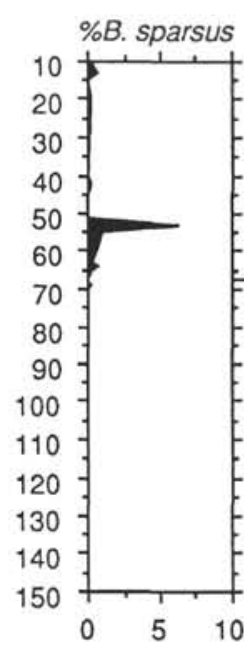

\%C. primus
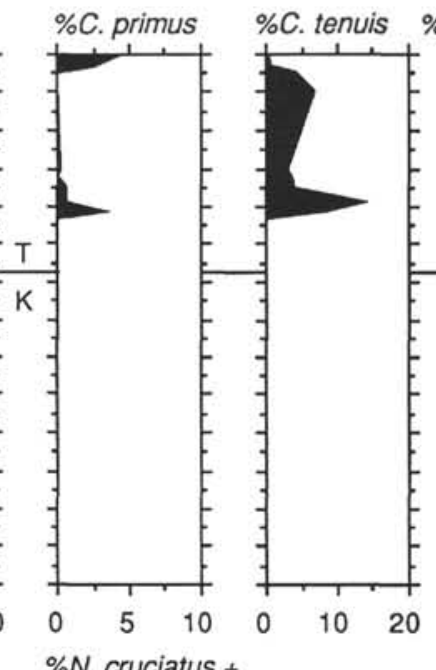

$\%$ P. dimorphosus

\%C. pelagicus

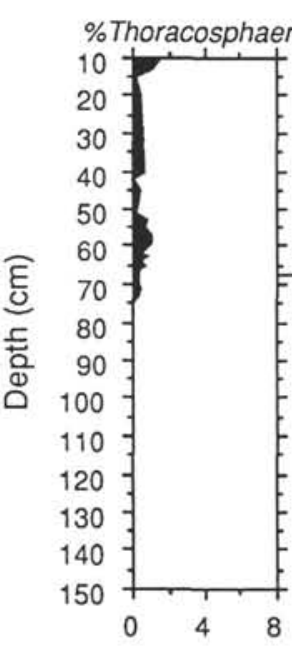

N. crassus
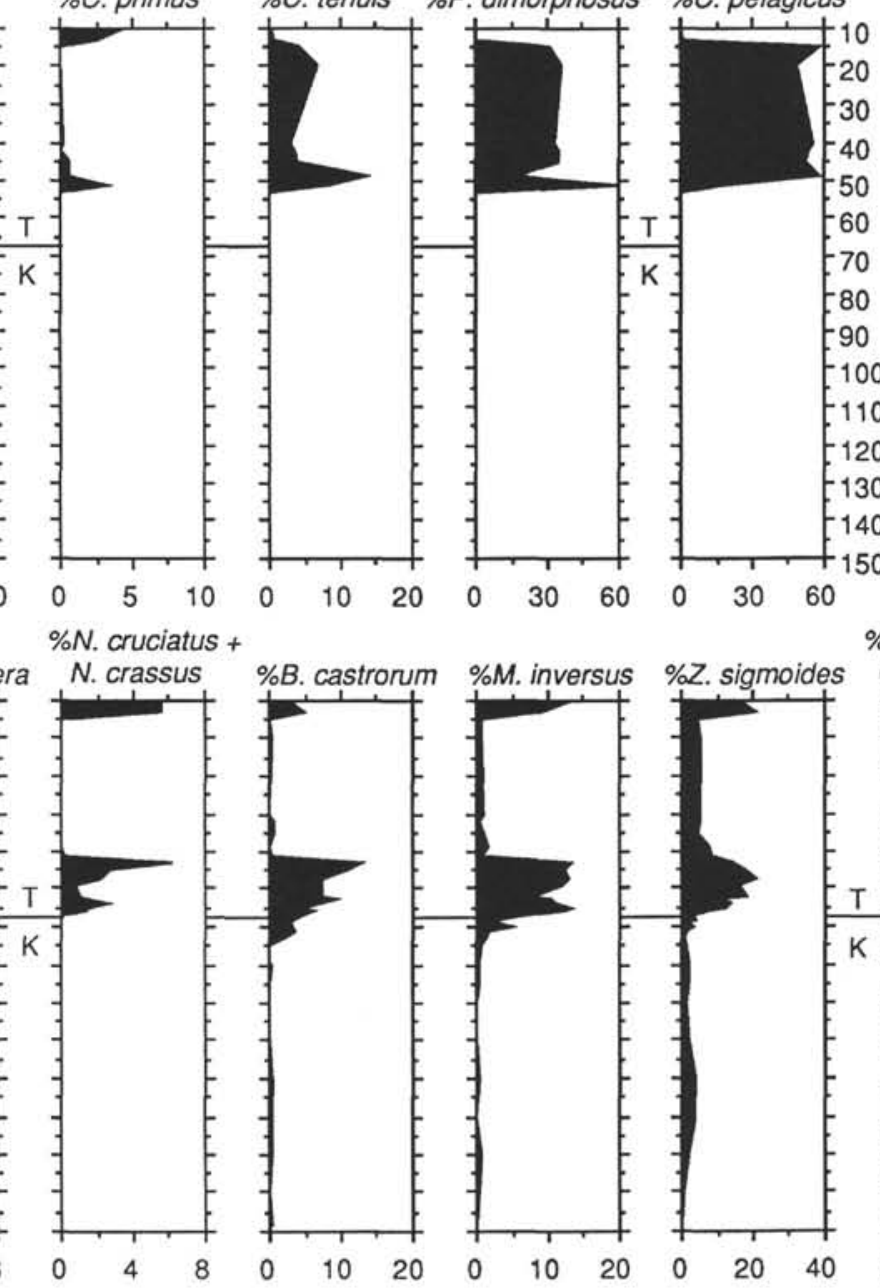

$\%$ C. alta +
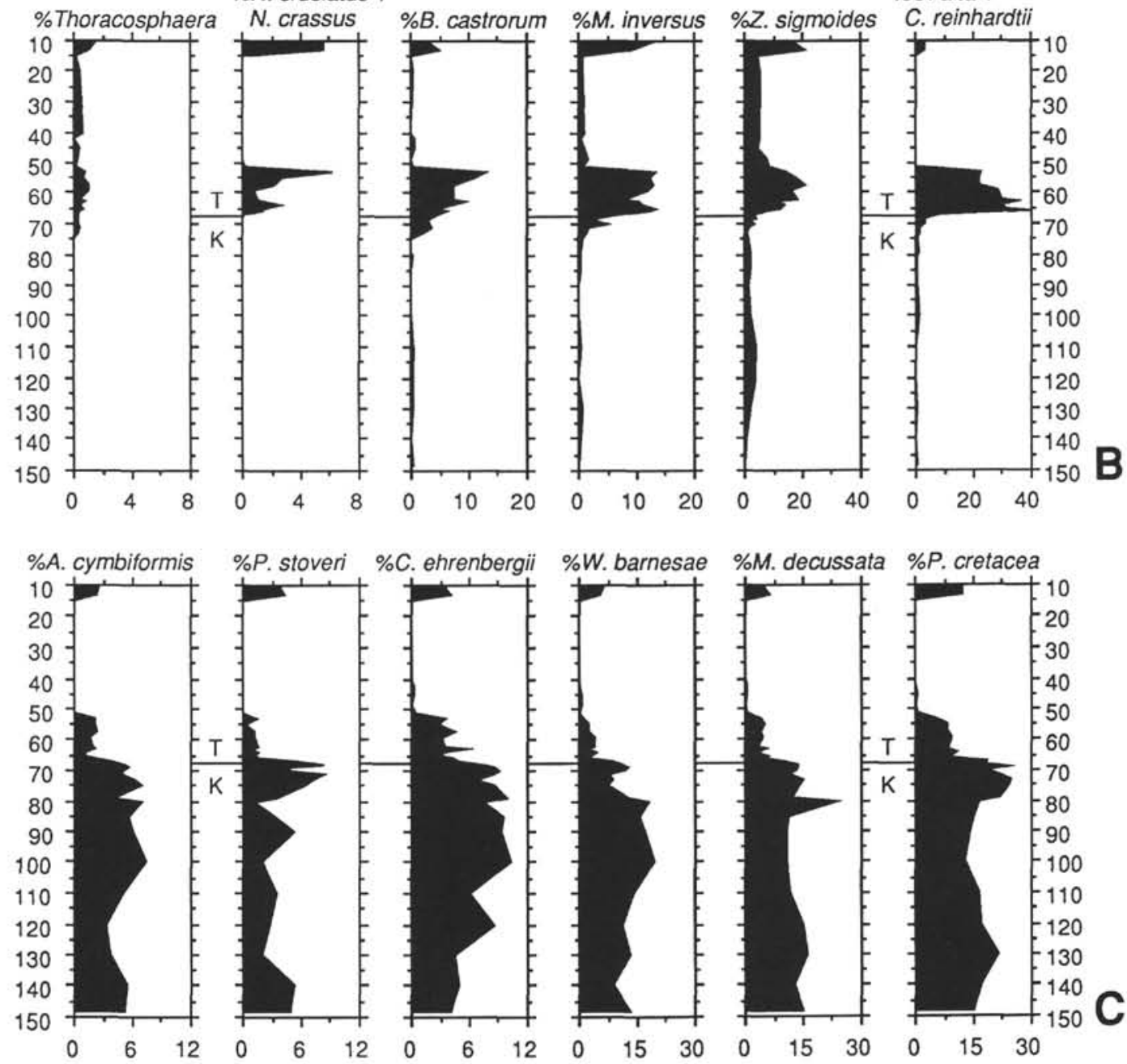

Figure 6. Percentage abundance of selected individual nannofossil species across the Cretaceous/Tertiary boundary of Section 122-761C-3R-3, 10-150 cm. A. Tertiary taxa. B. Survivor species. C. Cretaceous taxa. (Note: Scale changes along the percent axis (horizontal) of each graph.) 
and Perch-Nielsen (1979b) noted high abundances in several Danish sections. Abundance blooms have been recorded from several sections of southern France such as at Biarritz (PerchNielsen, 1979c), Bidart, and Pointe Sainte-Anne (Seyve, 1990). In deep-sea cores, Thierstein and Okada (1979) reported an abundance bloom of Cyclagelosphaera at North Atlantic Site 384 ; however, these taxa only rarely occur at the high-latitude Weddell Sea Site 690 (Pospichal and Wise, 1990) and at Indian Ocean Site 738 (Wei and Thierstein, 1991) and Site 752 (Pospichal, 1991).

Thierstein (1981) notes that Cyclagelosphaera is a neritic species, thus more tolerant of the sometimes ecologically stressful conditions associated with this type of environment and, more than likely, with the adverse conditions present during the $\mathrm{K} / \mathrm{T}$ transition. However, the significance of the geographic distribution of abundance blooms of this species above the $\mathrm{K} / \mathrm{T}$ boundary is not yet fully understood. Data from the aforementioned sites suggest that abundance blooms appear to be restricted to low and middle latitudes and possibly associated with shallower paleodepths. With this in mind, the early Danian conditions at Site 761 would also appear to have been favorable for an abundance bloom of Braarudosphaera and/or Thoracosphaera; however, no blooms of these species occur here. Therefore, it may be that localized or regional environmental factors ultimately determine which of these tolerant species will bloom at any one locality.

\section{Tertiary}

The Tertiary assemblage includes taxa that appear at or above the Cretaceous/Tertiary boundary. The first Tertiary form to appear here is Biantholithus sparsus. One specimen is noted below the contact at $69 \mathrm{~cm}$, which may be due to bioturbation. This usually rare species is consistently present starting at $66 \mathrm{~cm}$ and attains a peak abundance of nearly $7 \%$ of the assemblage at $53 \mathrm{~cm}$, which is just below the Subzone CP1a/CP1b boundary (Fig. 6, Table 1). The origin of this unusually high abundance of this species is not known.

The next Tertiary taxa to appear are Coccolithus (C. cavus and $C$. pelagicus), Cruciplacolithus tenuis, C. primus (large and small), and Prinsius dimorphosus. These species all appear abruptly and are abundant in the sample at $51 \mathrm{~cm}$ (Fig. 6 , Table 1). This sudden appearance probably indicates the presence of an unconformity between $51 \mathrm{~cm}$ and the next lowest sample studied at $53 \mathrm{~cm}$. This corresponds to a slight color change from dark to lighter green at this level in the core.

Normally, $C$. primus precedes $C$. tenuis in the sequence with the smaller forms appearing first, followed by the larger forms which appear at about the same time as $C$. tenuis. The simultaneous first occurrence (FO) here of smaller $C$. primus and $C$. tenuis also suggests the presence of a hiatus. Furthermore, in the highly expanded Danian section of southern Indian Ocean Site 752, it was noted that the first Prinsius to occur are very small forms (1.5-2 $\mu \mathrm{m})$ (Pospichal, 1991). In the present section, the first forms are of the larger variety (3-4 $\mu \mathrm{m})$ noted to occur later at Site 752 .

Prinsius dimorphosus is the most dominant taxon immediately above this hiatus in the sample at $51 \mathrm{~cm}$, accounting for $60 \%$ of the total assemblage. It is replaced as the most abundant taxon, however, by Coccolithus, which reaches abundances between $50 \%$ and $60 \%$ in the samples from $49 \mathrm{~cm}$ up to $15 \mathrm{~cm}$ (Fig. 5, Table 1). In these samples, $C$. primus and C. tenuis compose between $5 \%$ and $15 \%$ of the assemblage and Coccolithus subpertusus and Neochiastozygus sp. are also present but rare.
A few forms tentatively identified as Chiasmolithus danicus were also noted to occur sporadically, which may be contaminants. Ideally, $C$. danicus should be more accurately identified using the scanning electron microscope because in the light microscope it can be difficult to differentiate from its predecessor, Cruciplacolithus edwardsii.

Compared to low-latitude Cretaceous/Tertiary localities such as that at El Kef, Tunisia (Perch-Nielsen, 1981), the Tertiary assemblage of Site 761 lacks taxa such as Neobiscutum romeinii, $N$. parvulum, and Futyania petalosa, which are known to appear stratigraphically in that order (Perch-Nielsen, 1981). The latter species appears sometime between the first occurrence of $C$. primus and the first $C$. tenuis. The absence of these taxa could be the result of the abovementioned hiatus, latitudinal differences, or local environmental factors. Of the three species, $F$. petalos $a$ appears to be more widely distributed (Perch-Nielsen et al., 1982). Blooms have been reported at El Kef (Perch-Nielsen, 1981), Gubbio (Monechi, 1979), Barranco del Gredero, Spain (Romein, 1977), and the Brazos River (Jiang and Gartner, 1986). This form is present, although very rare, at the high-latitude Site 752 (paleolatitude $=50^{\circ} \mathrm{S}$ ) and at Site 750 (paleolatitude $=$ $57^{\circ} \mathrm{S}$ ) of the Indian Ocean (Pospichal, 1991).

Additional comparisons with the high-latitude sites of the Indian Ocean reveal that the Tertiary assemblage of Site 761 also lacks components of the austral realm, which further emphasizes a mid-latitude location. Wei and Thierstein (1991) and Ehrendorfer and Aubry (in press) report abundant Hornibrookina in Subzone CP1a-CP1b sediments from Sites $738\left(63^{\circ} \mathrm{S}\right)$ and $750\left(57^{\circ} \mathrm{S}\right)$, respectively. This form, which is also quite abundant at the extreme high-latitude Site 690 (Pospichal and Wise, 1990), is absent in the samples studied here and was not reported from the Paleocene of this or any other Leg 122 sites (Siesser and Bralower, this volume). This could also be attributed to a hiatus but is more likely to be a factor of paleolatitude. The abundance of Hornibrookina drops off considerably between Sites 750 (15\%-20\% maximum abundance; paleolatitude $=57^{\circ} \mathrm{S}$ ) (Ehrendorfer and Aubrey, in press) and the more northerly Site $752(0 \%-3 \%$; paleolatitude $\left.=50^{\circ} \mathrm{S}\right)($ Pospichal, 1991). Hence, its absence or rarity at the estimated $30^{\circ} \mathrm{S}$ paleolatitude for Site 761 may be expected.

\section{Error Analysis}

The results of the error analysis for the major Cretaceous, survivor, and Tertiary taxa are plotted in Figure 7. This plot shows how the relative size of the confidence limits decreases with increasing percentage. Some artificial data are introduced in these plots; for example, the upper confidence limit of Tertiary species in the Cretaceous is shown to be greater than 0 , when we know that these taxa do not occur below the boundary. Probably the most significant application of this analysis is on the evaluation of fluctuations in percentages of survivor (Fig. 7B) and Cretaceous taxa (Fig. 7C) above the boundary. In the case of all of the Cretaceous species with the exception of Prediscosphaera stoveri, the lower limit of confidence below the boundary is predominantly higher than the higher limit of confidence above the boundary. Thus, in these taxa, the change at the boundary is real and not a result of random noise. In the case of the survivors, most taxa peak between 66 and $55 \mathrm{~cm}$. With the exception of Thoracosphaera, the confidence limits clearly show that the abundances of these taxa in this interval are greater than the abundance in the overlying samples. Therefore, the decline in the relative proportion of most survivors above $55 \mathrm{~cm}$ is real and not the result of random noise. 

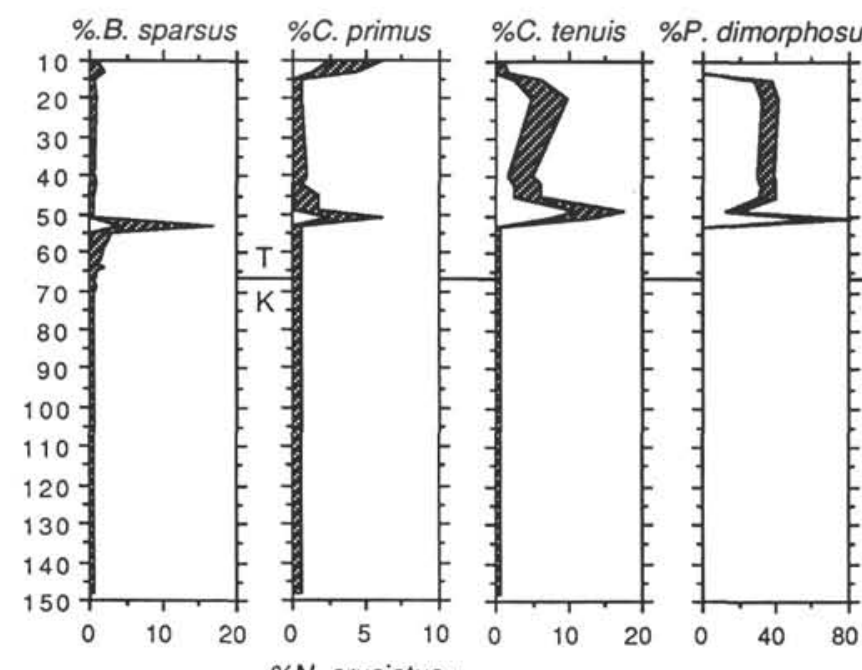

\%C. pelagicus
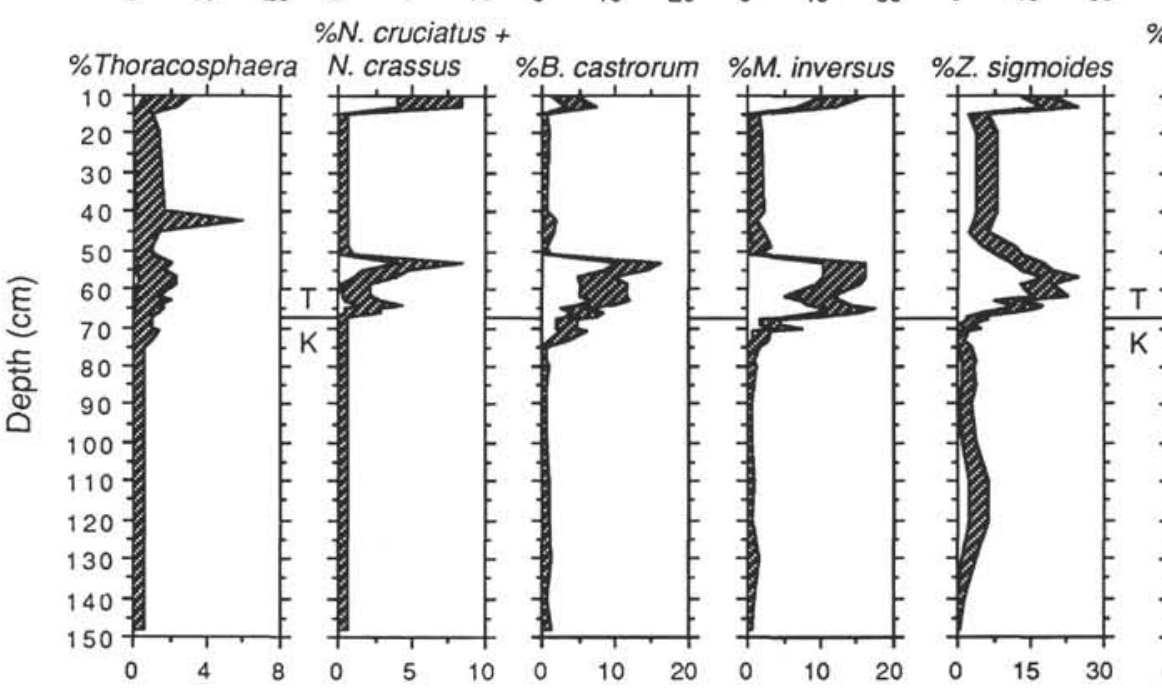

\%C. alta +
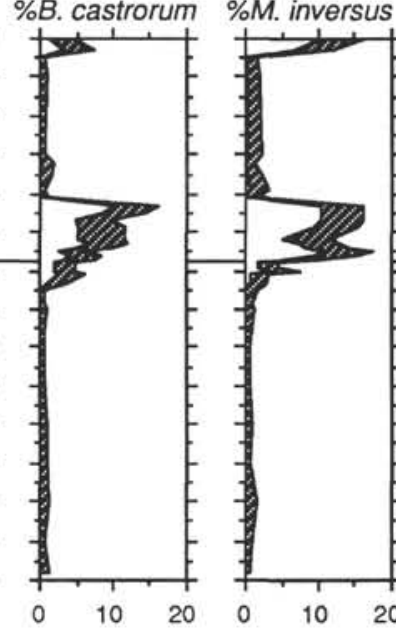

$\%$ Z. sigmoides

C. reinhardtii

$\%$ A. cymbiformis

$\% P$. stoveri

$\%$ C.ehrenbergii

$\%$ W. barnesae
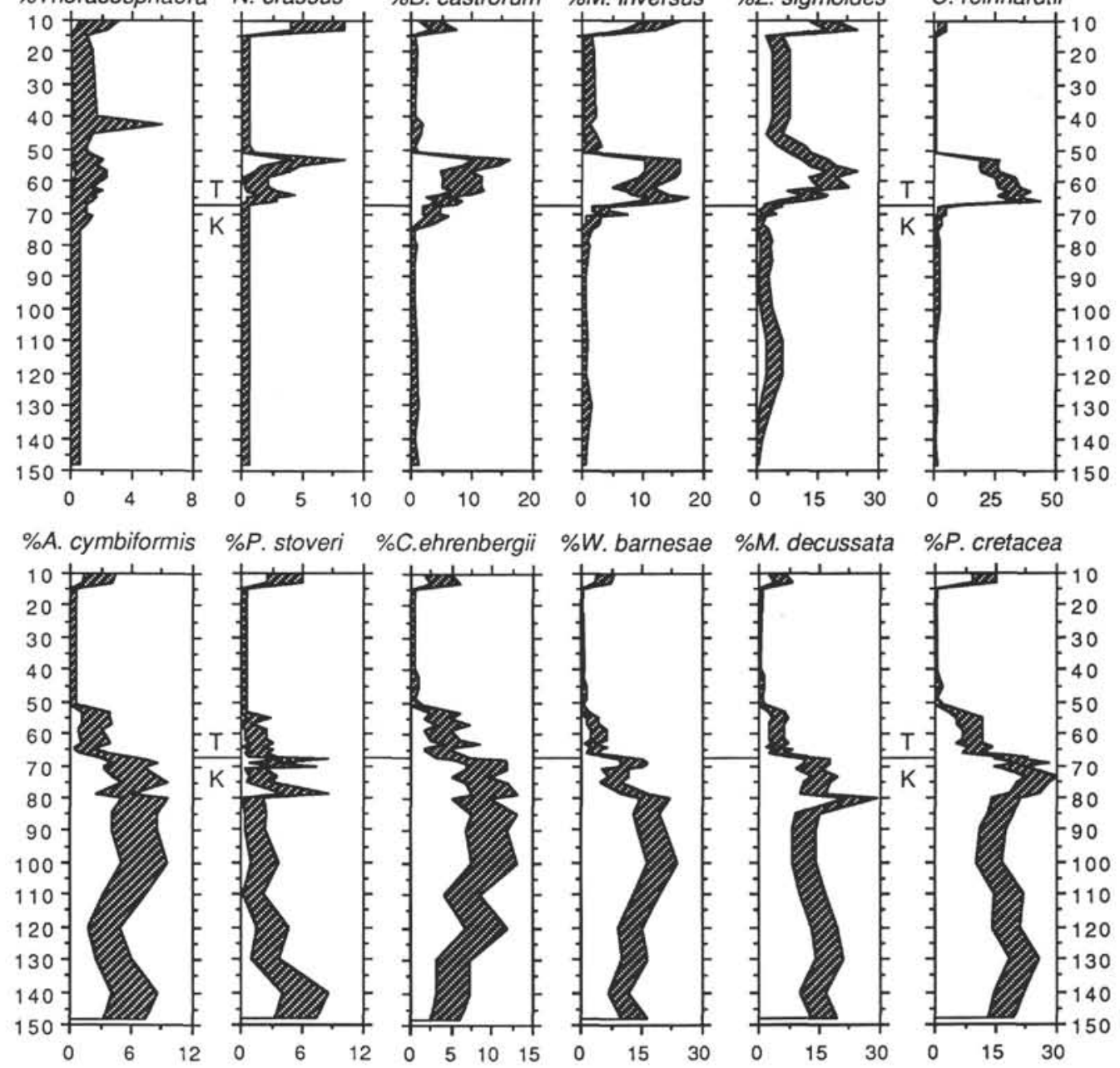

$\%$ M. decussata

\section{$\% P$. cretacea}

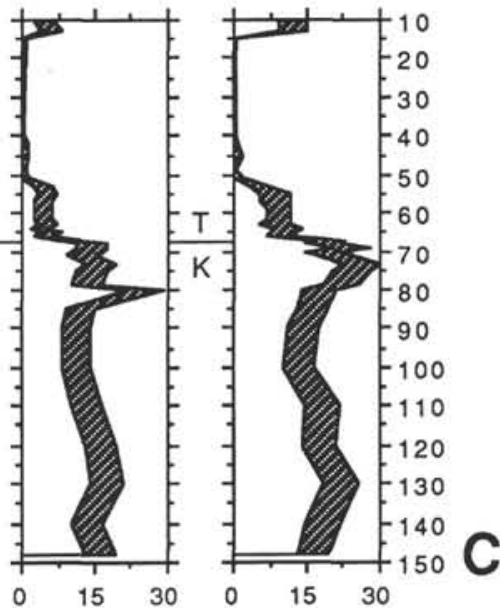

Figure 7. Confidence limits for the percentages of Cretaceous, survivor, and Tertiary taxa calculated at the 95th percent interval of confidence given a sample size of 500 . Shaded pattern indicates area between lower (to left) and upper (to right) confidence limit. A. Tertiary taxa. B. Survivor species. C. Cretaceous taxa. See text for discussion. 
A second application of this analysis will be in comparison of the data generated here with other data sets in which percentages and number of specimens counted are different.

\section{Biostratigraphy}

The zonation schemes for calcareous nannofossils used in this report are that of Okada and Bukry (1980) for the Danian and Sissingh (1977) for the Maestrichtian. The boundary is defined here on paleontologic criteria and lithologic criteria. The above-mentioned biozonation schemes define the boundary on the last occurrence of Cretaceous species. Unfortunately, mixing by bioturbation in Hole $761 \mathrm{C}$, as in most sections, precludes the use of this definition. Instead, the first occurrence of the calcareous nannofossil Biantholithus sparsus (Perch-Nielsen, 1979a) is used in conjunction with the drop in the percentage of Cretaceous forms and the sharp increase in the percentage of forms which cross the boundary, the survivors. This assemblage change occurs between 66 and $68 \mathrm{~cm}$ in Section 122-761C-3R-3 (Table 1). The nannofossil assemblage of the sample at $67 \mathrm{~cm}$ appears to be a natural mixture between those of the underlying and overlying samples. Biantholithus sparsus consistently occurs starting at 66 $\mathrm{cm}$. One specimen was noted below this at $69 \mathrm{~cm}$, probably as a result of bioturbation.

As noted in the previous section, the presence of an unconformity is possible at the $\mathrm{K} / \mathrm{T}$ boundary horizon of this section. We denote the boundary by the distinct and abrupt shift in nannofossil assemblages, which may be construed as evidence for an unconformity. Further evidence is suggested by the fact that there is no interval of sediment between the level at which we place the boundary and the FO of $B$. sparsus, which is the case in the standard section at El Kef (Perch-Nielsen, 1981) and at Site 752 (Pospichal, 1991).

The Subzone CP1a/CP1b (NP1/NP2) boundary is defined here by the FO of Cruciplacolithus tenuis, which for this study includes all Cruciplacolithus greater than $7 \mu \mathrm{m}$. In Section 122-761C-3R-3, the FO of $C$. tenuis is at $51 \mathrm{~cm}$ and the thickness of Subzone CP1a is thus about $16 \mathrm{~cm}$. This is quite thin when compared to the most complete Cretaceous/Tertiary sections due to a hiatuses between Subzones CP1a and $\mathrm{CP} 1 \mathrm{~b}$ and probably at the $\mathrm{K} / \mathrm{T}$ boundary. The thickness of Subzone CP1a in a number of land, ODP, and DSDP localities is compared in Figure 8. Of the drill core sections, Site 752 contains the most expanded Subzone CP1a at approximately 5 $\mathrm{m}$ thick. This interval is between 0.5 and $3 \mathrm{~m}$ in other deep-sea sections. Sedimentation rates were higher in the marginal and hemipelagic sequences such as at El Kef, Tunisia, which is an expanded section commonly used as a standard for all other Cretaceous/Tertiary sites (Perch-Nielsen et al., 1982). Likewise, the section at Site 761 was deposited in a shelf setting and should be more comparable in thickness to the expanded marginal sections and not the thin deep-sea sequences, and thus this may also indicate that much sediment may be missing due to hiatuses.

The zonal assignment for the remainder of Core 122$761 C-3 R$ to Maestrichtian Zone CC26 is based on the presence of few Micula murus and rare Nephrolithus frequens. According to Haq, von Rad, O'Connell, et al. (1990), Zone CC26 is at least present from Sample 122-761C-3R-3, $67 \mathrm{~cm}$, to the base of Core 122-761C-3R, which constitutes a thickness of $4.8 \mathrm{~m}$. However, the true thickness of this zone in Hole $761 \mathrm{C}$ is not known because the hole was spot-cored, a method that leaves gaps in the record. The next core, 122-761C-5R, was taken about $50 \mathrm{~m}$ below Core $122-761 \mathrm{C}-3 \mathrm{R}$ and is dated as AlbianTuronian.

The uppermost Maestrichtian marker, $M$. prinsii (PerchNielsen, 1979d) was not observed in this study or by the shipboard scientists (Haq, von Rad, O'Connell, et al., 1990). The absence of this species could be a result of the following factors: (1) overgrowth could inhibit distinction between this form and $M$. murus, (2) an unconformity encompassing the topmost Maestrichtian may be present, and (3) environmental exclusion due to the higher latitudinal position of this site at $\mathrm{K} / \mathrm{T}$ boundary time. The paleolatitude of this site based on reconstruction of the Indian Ocean before the break up of Australia and Antarctica was close to $30^{\circ} \mathrm{S}$ (Fig. 2). PerchNielsen et al. (1982) report the presence of $M$. prinsii at the higher latitude location of Denmark and at South Atlantic Site 524, which had approximately the same paleolatitude as Site 761. Thus, the possibility of missing section or preservational control are likely reasons for the absence of $M$. prinsii in the present section.

\section{SUMMARY}

The Cretaceous/Tertiary boundary at Site 761 is determined to be biostratigraphically complete in that all nannofossil zones can be distinguished. However, sedimentation was not continuous throughout the earliest Danian as the abrupt and simultaneous first occurrences of Cruciplacolithus tenuis, C. primus, Coccolithus spp., and Prinsius dimorphosus indicate the presence of an unconformity that separates Subzones CP1a and CP1b. In addition, Subzone CP1a is only $16 \mathrm{~cm}$ thick, which is less than in the most complete Cretaceous/ Tertiary sections (Fig. 8).

Likewise, sedimentation across the Cretaceous/Tertiary boundary at this site may not have been continuous. The rather abrupt change in nannofossil assemblages along with lithologic changes, which is complicated further by a drilling disturbed contact, may also suggest an incomplete section. Furthermore, the lack of Micula prinsii at this site may also indicate that the topmost Maestrichtian is not present, although preservation and paleolatitude may also explain the absence of this species.

Cretaceous nannofossils at this site are characteristic of the mid-latitudes. Prediscosphaera cretacea and Micula decussata are the most abundant components of the assemblages that are rapidly replaced by the "survivor" assemblage dominated by Cyclagelosphaera. The survivor assemblage of Subzone CPla at Site 761 contains no abundance bloom of Thoracosphaera or Braarudosphaera, which are commonly found at other, but not all, Cretaceous/Tertiary localities.

The Tertiary assemblage is completely dominated by Coccolithus pelagicus and Prinsius dimorphosus in Subzone CP1b. Cruciplacolithus tenuis is common and $C$. primus is a minor component. Just below the $\mathrm{CP} 1 \mathrm{a} / \mathrm{CP} 1 \mathrm{~b}$ boundary, $B i$ antholithus sparsus is surprisingly common, much more so than in higher latitude Indian Ocean Cretaceous/Tertiary sites.

In conclusion, the basic pattern of nannofossil assemblage turnover across the Cretaceous/Tertiary boundary at Site 761 is quite similar to other sections. The Cretaceous species are rapidly replaced by opportunistic survivors which, in turn, give way to a rapidly evolving Tertiary nannoflora. Differences among the assemblages at various Cretaceous/Tertiary localities are largely determined by the particular group of species that dominates the survivor assemblage.

\section{ACKNOWLEDGMENTS}

This study was supported by Legs 121 and 122 U.S. Science Advisory Council funds, National Science Foundation grant DDP-8917976, an equipment grant from the Amoco Foundation, and an Aylesworth Foundation Fellowship to JJP. We thank W. G. Siesser for numerous shipboard observations. The suggestions by reviewers, K. von Salis PerchNielsen and J. A. Crux, were greatly appreciated. S. W. Wise 


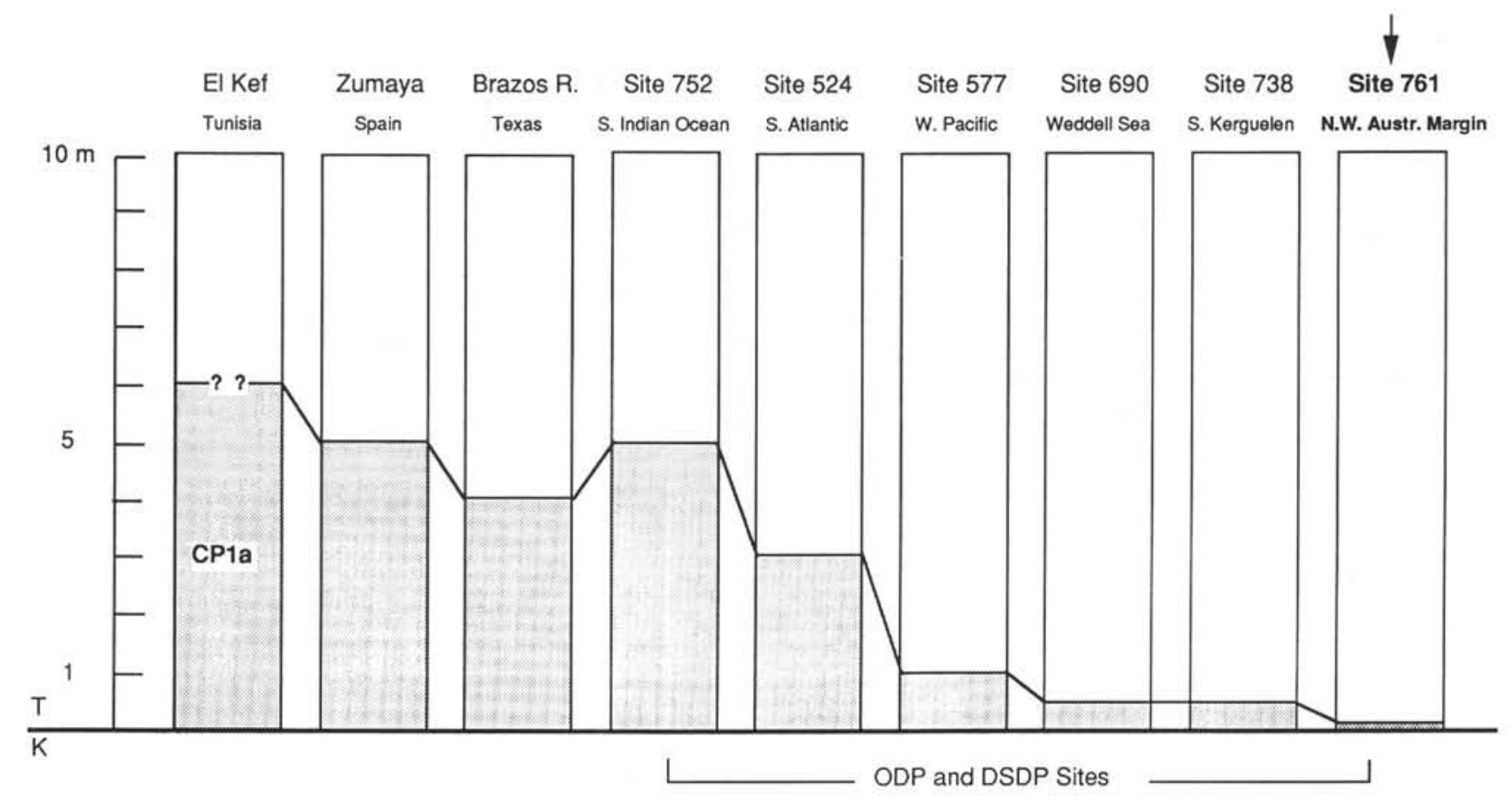

Figure 8. Comparison of the thickness of Subzone CP1a (NP1) from various land-based and DSDP/ODP Cretaceous/Tertiary sections. Thicknesses are implied for sections in which the standard zonation schemes were not applied (after Pospichal and Wise, 1990).

also provided helpful suggestions. Special thanks goes to F.F.A. Kaharoeddin for assistance with analysis of the sedimentary component of the smear slides. N. Vaughan assisted with photography and Amy Jo Jarvis and K. J. Jarvis helped with the plates.

\section{REFERENCES}

Ehrendorfer, T., and Aubry, M.-P., in press. Calcareous nannoplankton changes across the Cretaceous/Paleocene boundary in the Southern Indian Ocean (ODP Site 750A). In Schlich, R., Wise, S. W., Jr., et al., Proc. ODP, Sci. Results, 120: College Station, TX (Ocean Drilling Program).

Haq, B. U., von Rad, U., O'Connell, S., et al., 1990. Proc. ODP, Init. Repts., 122: College Station, TX (Ocean Drilling Program).

Jiang, M. J., and Gartner, S., 1986. Calcareous nannofossil succession across the Cretaceous/Tertiary boundary in east-central Texas. Micropaleontology, 32:232-255.

Mainland, D., Herrara, L., and Sutcliffe, M. I., 1956. Tables for Use With Binomial Samples: New York (Dept. of Medical Statistics, New York Univ. College of Medicine).

Monechi, S., 1979. Variations in nannofossil assemblage at the Cretaceous/Tertiary boundary in the Bottaccione section (Gubbio, Italy). In Christensen, W. K., and Birkelund, T. (Eds.), Cretaceous-Tertiary Boundary Events (Vol. 11): Copenhagen (Univ. of Copenhagen), 164-169.

Okada, H., and Bukry, D., 1980. Supplementary modification and introduction of code numbers to the low-latitude coccolith biostratigraphic zonation (Bukry, 1973; 1975). Mar. Micropaleontol., 5:321-325.

Perch-Nielsen, K., 1969. Die Coccolithen einiger Dänischer Maastrichtien- und Danienlokalithaten. Bull. Geol. Soc. Den., 19:51-69. 1979a. Calcareous nannofossil zonation at the Cretaceous/ Tertiary boundary in Denmark. In Birkelund, T., and Bromley, R. G. (Eds.), Cretaceous-Tertiary Boundary Events (Vol. 1): Copenhagen (Univ. of Copenhagen), 115-135.

1979b. Calcareous nannofossils in Cretaceous/Tertiary boundary sections in Denmark. In Christensen, W. K. and Birkelund, T. (Eds.), Cretaceous-Tertiary Boundary Events (Vol. 2): Copenhagen (Univ. of Copenhagen), 120-126. 1979c. Calcareous nannofossils at the Cretaceous/Tertiary boundary near Biarritz, France. In Christensen, W. K., and Birkelund, T. (Eds.), Cretaceous-Tertiary Boundary Events (Vol. 2): Copenhagen (Univ. of Copenhagen), 151-155.

1979d. Calcareous nannofossils from the Cretaceous between the North Sea and the Mediterranean. In Wiedmann, J. (Ed.), Aspekte der Kreide Europeas. Int. Union Geol. Sci., Ser. A, 6:223-272.

1981. Nouvelles observations sur les nannofossiles calcaires à la limite Crétacé-Tertiare près de El Kef (Tunisie). Cah. Micropaleontol., 3:25-36.

Perch-Nielsen, K., McKenzie, J. A., and He, Q. X., 1982. Biostratigraphy and isotope stratigraphy and the "catastrophic" extinction of calcareous nannoplankton at the Cretaceous/Tertiary boundary. In Silver, L. T., and Schultz, H. (Eds.), Geological Implications of Impacts of Large Asteroids and Comets on the Earth. Spec. Pap. Geol. Soc. Am., 190:353-371.

Percival, S. F., and Fischer, A. G., 1977. Changes in calcareous nannoplankton in the Cretaceous-Tertiary biotic crisis at Zumaya, Spain. Evol. Theory, 2:1-35.

Pospichal, J. J., 1991. Calcareous nannofossils across the Cretaceous/ Tertiary boundary at Site 752, eastern Indian Ocean. In Weissel, J., Peirce, J., Taylor, E., Alt, J., et al., Proc. ODP, Sci. Results, 121: College Station, TX (Ocean Drilling Program), 395-414.

Pospichal, J. J., and Wise, S. W., Jr., 1990. Calcareous nannofossils across the K/T boundary, ODP Hole 690C, Maud Rise, Weddell Sea. In Barker, P. F., Kennett, J. P., et al., Proc. ODP, Sci. Results, 113: College Station, TX (Ocean Drilling Program), $515-532$.

Romein, A.J.T., 1977. Calcareous nannofossils from the Cretaceous/ Tertiary boundary interval in the Barranco del Gredero (Caravaca, Prov. Murcia, S. E. Spain), I and II. Proc. K. Ned. Akad. Wet., Ser. B, 80:256-279.

Seyve, C., 1990. Nannofossil biostratigraphy of the CretaceousTertiary boundary in the French Basque Country. Bull. Cent. Rech. Explor.-Prod. Elf-Aquitaine, 14:553-572.

Sissingh, W., 1977. Biostratigraphy of Cretaceous calcareous nannoplankton. Geol. Mijinbouw, 56:37-65.

Thierstein, H. R., 1981. Late Cretaceous nannoplankton and the change at the Cretaceous-Tertiary boundary. In Warme, J. E., 
Douglas, R. G., and Winterer, E. L. (Eds.), The Deep Sea Drilling Project: A Decade of Progress: Spec. Publ. Soc. Econ. Paleontol. Mineral., 32:355-394.

Thierstein, H. R., and Okada, H., 1979. The Cretaceous/Tertiary boundary event in the North Atlantic. In Tucholke, B. E., Vogt, P. R., et al., Init. Repts. DSDP, 43: Washington (U.S. Govt. Printing Office), 601-616.

Watkins, D. K., in press. Upper Cretaceous nannofossils from ODP Leg 120, Kerguelen Plateau, Southern Ocean. In Schlich, R., Wise, S. W., Jr., et al., Proc. ODP, Sci. Results, 120: Washington (U.S. Govt. Printing Office).

Wei, W., and Pospichal, J., 1991. Danian calcareous nannofossil succession at ODP Site 738 in the southern Indian Ocean. In Barron, J., Larsen, B., et al., Proc. ODP, Sci. Results, 119: College Station, TX (Ocean Drilling Program), 495-512.

Wei, W., and Thierstein, H. R., 1991. Upper Cretaceous and Cenozoic calcareous nannofossils of the Kerguelen Plateau (southern Indian Ocean) and Prydz Bay (East Antarctica). In Barron, J., Larsen, B., et al., Proc. ODP, Sci. Results, 119: College Station, TX (Ocean Drilling Program), 467-494.

Date of initial receipt: 30 May 1990

Date of acceptance: 4 March 1991

Ms 122B-187

\section{APPENDIX}

Calcareous Nannofossils Considered in this Report (In Alphabetical Order of Generic Epithets)

Tertiary

Biantholithus sparsus Bramlette and Martini, 1964

Coccolithus cavus (Hay and Mohler) Perch-Nielsen, 1969

C. pelagicus (Wallich) Schiller, 1930

C. subpertusus (Hay and Mohler) Wei and Pospichal, 1991

Coccolithus sp.

Cruciplacolithus edwardsii Romein, 1979

C. primus Perch-Nielsen, 1977

C. tenuis (Stradner) Hay and Mohler, 1967

Futyania petalosa (Ellis and Lohmann) Varol, 1989

Hornibrookina Edwards, 1973a

Neobiscutum romeinii (Perch-Nielsen) Varol, 1989

N. parvulum (Romein) Varol, 1989

Neochiastozygus sp.

Prinsius dimorphosus (Perch-Nielsen) Perch-Nielsen, 1977

Survivors

Biscutum castrorum Black, 1959

Braarudosphaera bigelowii (Gran and Braarud) Deflandre, 1947

Cyclagelosphaera alta Perch-Nielsen, 1979a

C. reinhardtii (Perch-Nielsen) Romein, 1977

Lapideacassis sp.
Markalius apertus Perch-Nielsen, 1979a

M. inversus (Deflandre) Bramlette and Martini, 1964

Neocrepidolithus cruciatus (Perch-Nielsen) Perch-Nielsen, 1981a

N. neocrassus (Perch-Nielsen) Romein, 1979

N. fossus Romein, 1979

Thoracosphaera Kamptner, 1927

Zygodiscus sigmoides Bramlette and Sullivan, 1961

\section{Cretaceous}

Actinozygus regularis (Gorka) Gartner, 1968

Arkhangelskiella cymbiformis Vekshina, 1959

A. specillata Vekshina, 1959

Bidiscus rotatorius Bukry, 1969

Biscutum constans (Gorka) Black, 1959

Biscutum sp. 1

Biscutum sp. 2

Chiastozygus amphipons (Bramlette and Martini) Gartner, 1968

Chiastozygus? spp.

Chiastozygus interruptus Bukry, 1969

Chiastozygus sp. aff. C. interruptus

Corollithion exiguum Stradner, 1961

C.? madagaskarensis Perch-Nielsen, 1973

C. rhombicus (Stradner and Adamiker) Bukry, 1969

Cretarhabdus conicus Bramlette and Madini, 1964

C. crenulatus Bramlette and Martini, 1964

C. surirellus (Deflandre and Fert) Thierstein, 1971

Cribrosphaerella daniae Perch-Nielsen, 1973

C. ehrenbergii (Arkhangelsky) Deflandre in Piveteau, 1952

Cylindralithus Bramlette and Martini, 1964

Eiffellithus turriseiffelii (Deflandre and Fert) Reinhardt, 1965

Kamptnerius magnificus Deflandre, 1959

Lithraphidites quadratus Bramlette and Martini, 1964

Lucianorhabdus cayeuxii Deflandre, 1959

Manivitella pemmatoidea (Deflandre in Manivit) Thierstein, 1971

Microrhabdulus decoratus Deflandre, 1959

Micula decussata Vekshina, 1959

M. murus (Martini) Bukry, 1973

M. prinsii Perch-Nielsen, 1979d

Nephrolithus frequens frequens Gorka, 1957

N. frequens miniporus (Reinhardt and Gorka) Pospichal and Wise, 1990b

Prediscosphaera arkhangelskyi (Reinhardt) Perch-Nielsen, 1984a

$P$. cretacea (Arkhangelsky) Gartner, 1968

$P$. grandis Perch-Nielsen, 1979d

P. spinosa (Bramlette and Martini) Gartner, 1968

$P$. stoveri (Perch-Nielsen) Shafik and Stradner, 1971

Tranolithus minimus (Bukry) Perch-Nielsen, 1984a

Vagalapilla aachena Bukry, 1969

Watznaueria barnesae (Black in Black and Barnes) Perch-Nielsen, 1968

Zeugrhabdotus embergeri (Noël) Perch-Nielsen, 1984a

Z. spiralis Bramlette and Martini, 1964

Zygodiscus sp. cf. 

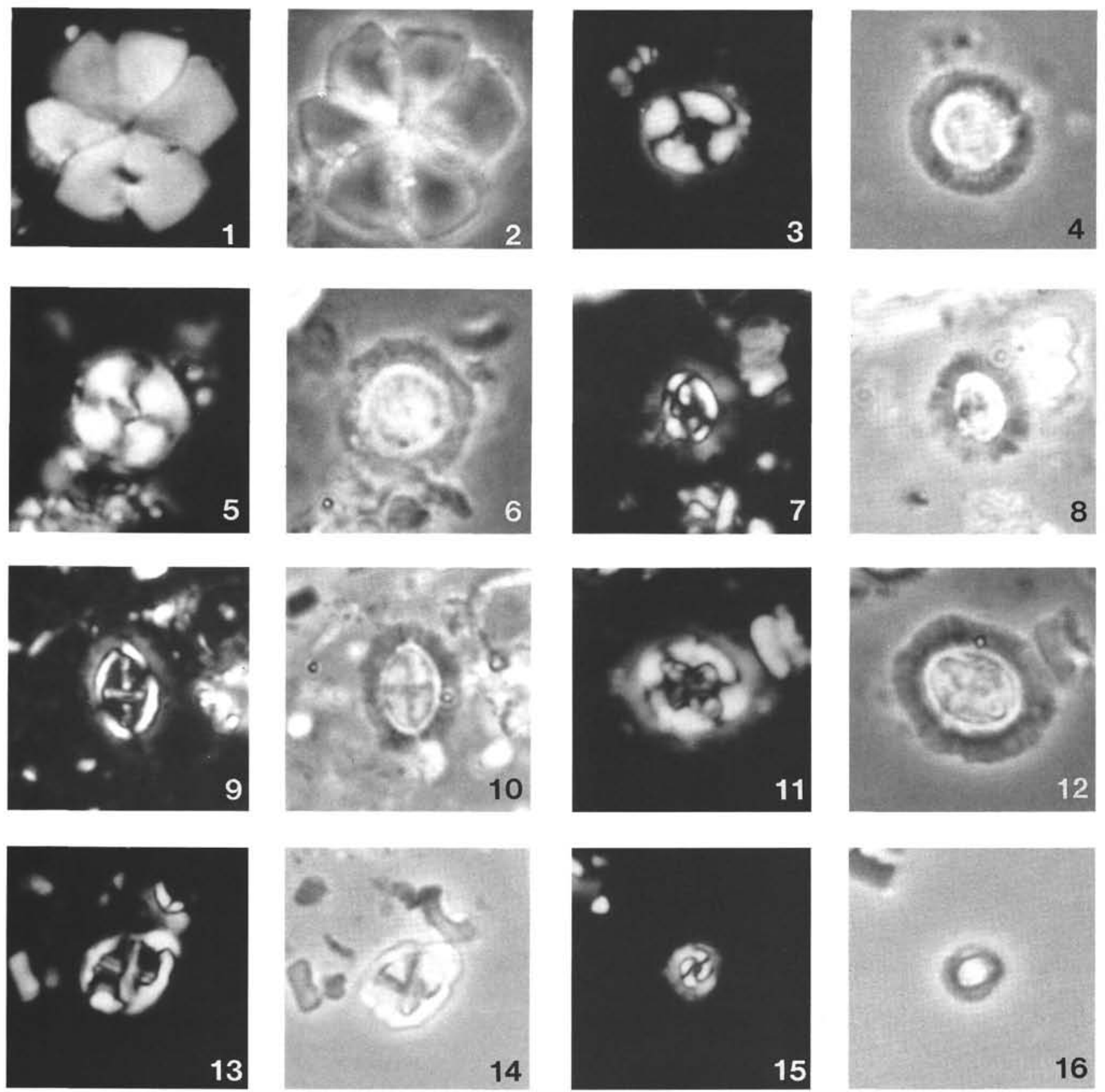

Plate 1. 1, 2. Biantholithus sparsus, Sample 122-761C-3R-3, $10 \mathrm{~cm},(1)$ polarized, (2) phase contrast. 3, 4. Coccolithus cavus, Sample 122-761C-3R-3, $15 \mathrm{~cm}$, (3) polarized, (4) phase contrast. 5, 6. C. subpertusus, Sample 122-761C-3R-3, 15 cm, (5) polarized, (6) phase contrast. 7, 8. Cruciplacolithus primus, Sample 122-761C-3R-3, $10 \mathrm{~cm}$, (7) polarized, (8) phase contrast. 9, 10. C. primus, Sample 122-761C-3R-3, $10 \mathrm{~cm}$, (9) polarized, (10) phase contrast. 11, 12. C. tenuis, Sample 122-761C-3R-3, $45 \mathrm{~cm}$, (11) polarized, (12) phase contrast. 13, 14. Neochiastozygus sp., Sample 122-761C-3R-3, $45 \mathrm{~cm},(13)$ polarized, (14) phase contrast. 15, 16. Prinsius dimorphosus, Sample 122-761C-3R-3, $45 \mathrm{~cm}$, (15) polarized, (16) phase contrast. Magnification for all figures is approximately $\times 3200$. 

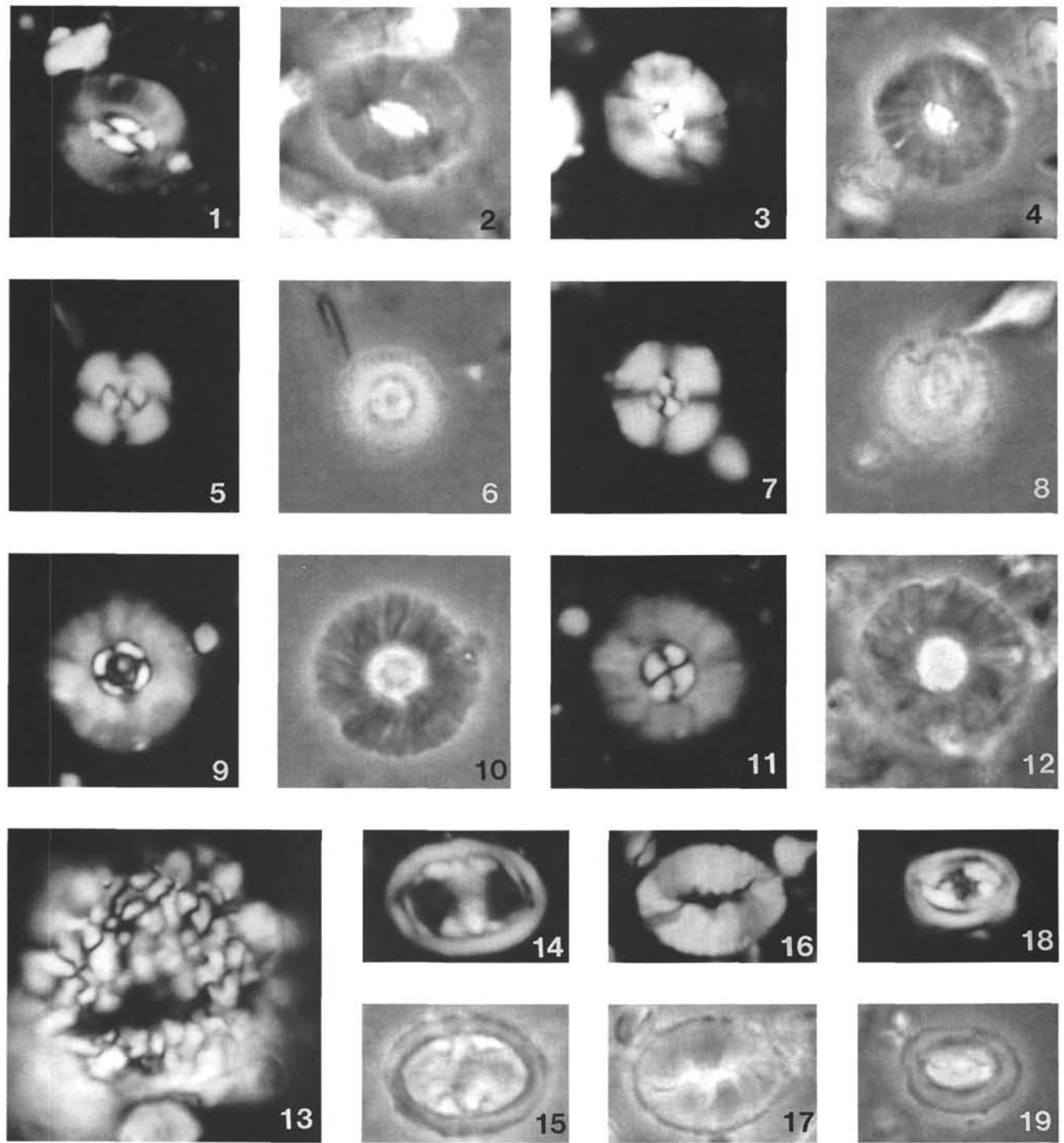

Plate 2. 1, 2. Biscutum castrorum, Sample $122-761 \mathrm{C}-3 \mathrm{R}-3,10 \mathrm{~cm},(1)$ polarized, (2) phase contrast. 3, 4. B. castrorum, Sample 122-761C-3R-3, $10 \mathrm{~cm}$, (3) polarized, (4) phase contrast. 5, 6. Cyclagelosphaera sp. cf. C. alta, Sample 122-761-3R-3, 10 cm, (5) polarized, (6) phase contrast. 7, 8. C. reinhardtii, Sample 122-761C-3R-3, $66 \mathrm{~cm},(7)$ polarized, (8) phase contrast. 9, 10. Markalius apertus, Sample 122-761C-3R-3, $10 \mathrm{~cm}$, (9) polarized, (10) phase contrast. 11, 12. M. inversus, Sample 122-761C-3R-3, 10 cm, (11) polarized, (12) phase contrast. 13. Thoracosphaera, Sample 122-761C-3R-3, $10 \mathrm{~cm}$, polarized. 14, 15. Zygodiscus sigmoides, Sample 122-761C-3R-3, 10 cm, (14) polarized, (15) phase contrast. 16, 17. Neocrepidolithus fossus, Sample 122-761C-3R-3, $10 \mathrm{~cm},(16)$ polarized, (17) phase contrast. 18, 19. $N$. neocrassus, Sample 122-761C-3R-3, $10 \mathrm{~cm},(18)$ polarized, (19) phase contrast.. Magnification for all figures is approximately $\times 3200$. 

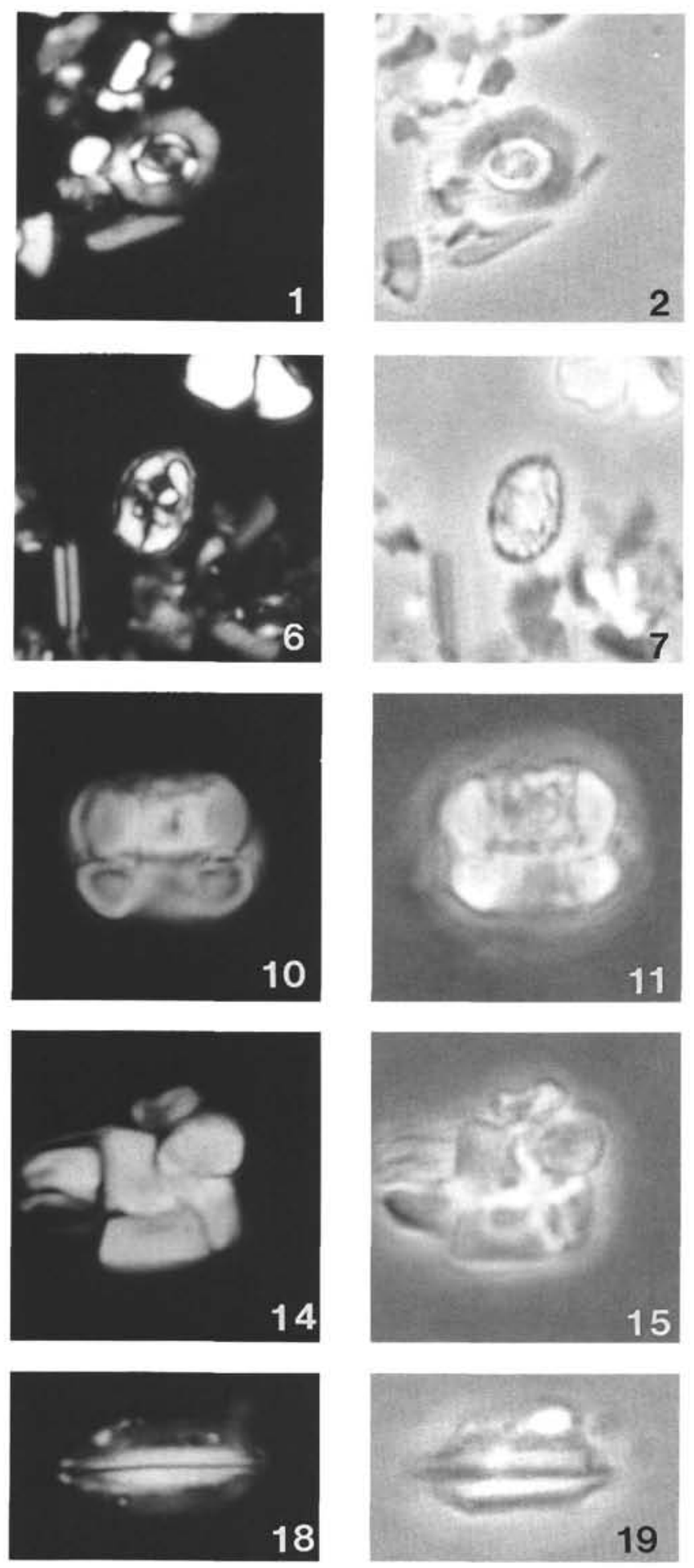
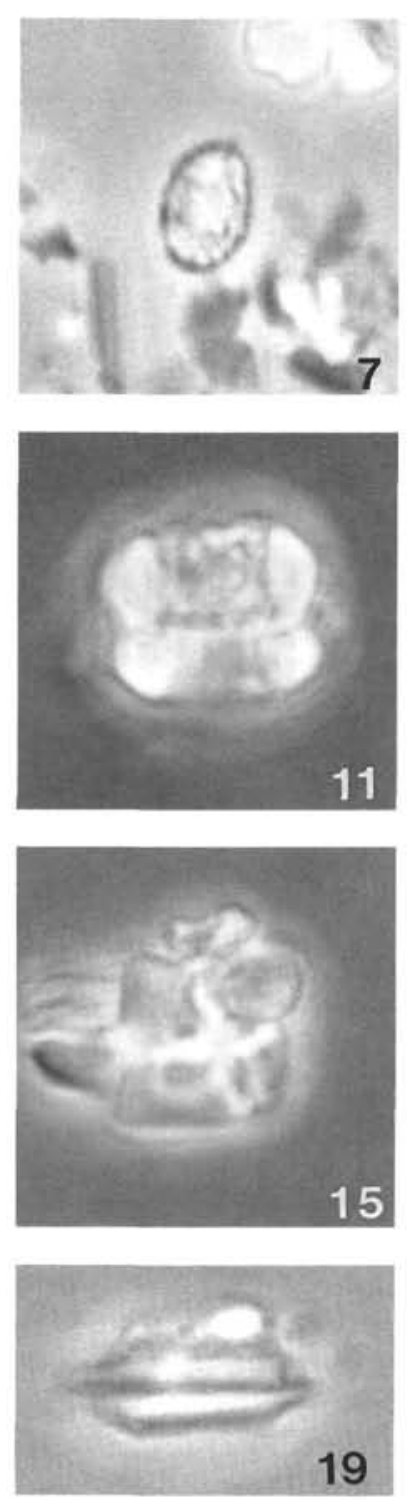
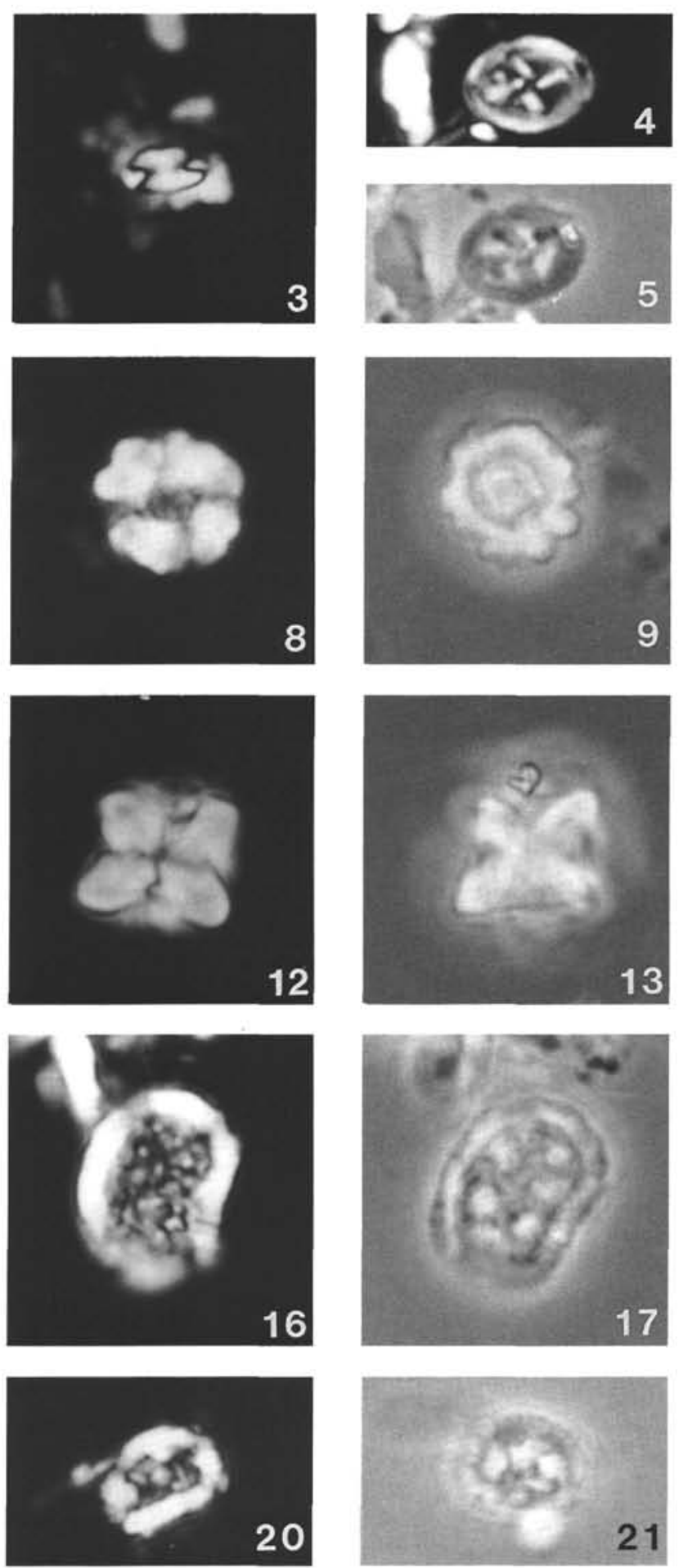

Plate 3. 1, 2. Biscutum sp. 1, Sample 122-761C-3R-3, $100 \mathrm{~cm}$, (1) polarized, (2) phase contrast. 3. Biscutum sp. 2, Sample 122-761C-3R-3, $68 \mathrm{~cm}$, polarized. 4, 5. Chiastozygus? sp., Sample 122-761C-3R-3, $100 \mathrm{~cm}$, (4) polarized, (5) phase contrast. 6, 7. Corollithion? madagaskarensis, Sample 122-761C-3R-3, $100 \mathrm{~cm}$, (6) polarized, (7) phase contrast. 8, 9. Cylindralithus sp., Sample 122-761C-3R-3, 130 $\mathrm{cm}$, (8) polarized, (9) phase contrast. 10, 11. Cylindralithus sp., Sample 122-761C-3R-3, $130 \mathrm{~cm}$, side view, (10) polarized, (11) phase contrast. 12, 13. Micula decussata, Sample 122-761C-3R-3, $68 \mathrm{~cm},(12)$ polarized, (13) phase contrast. 14, 15. M. murus, Sample 122-761C-3R-3, $120 \mathrm{~cm}$, (14) polarized, (15) phase contrast. 16, 17. Nephrolithus frequens frequens, Sample 122-761C-3R-3, 120 cm, (16) polarized, (17) phase contrast. 18, 19. Lithraphidites quadratus, Sample 122-761C-3R-3, $100 \mathrm{~cm}$, (18) polarized, (19) phase contrast. 20, 21. $N$. frequens miniporus, Sample 122-761C-3R-3, $100 \mathrm{~cm},(20)$ polarized, (21) phase contrast. 

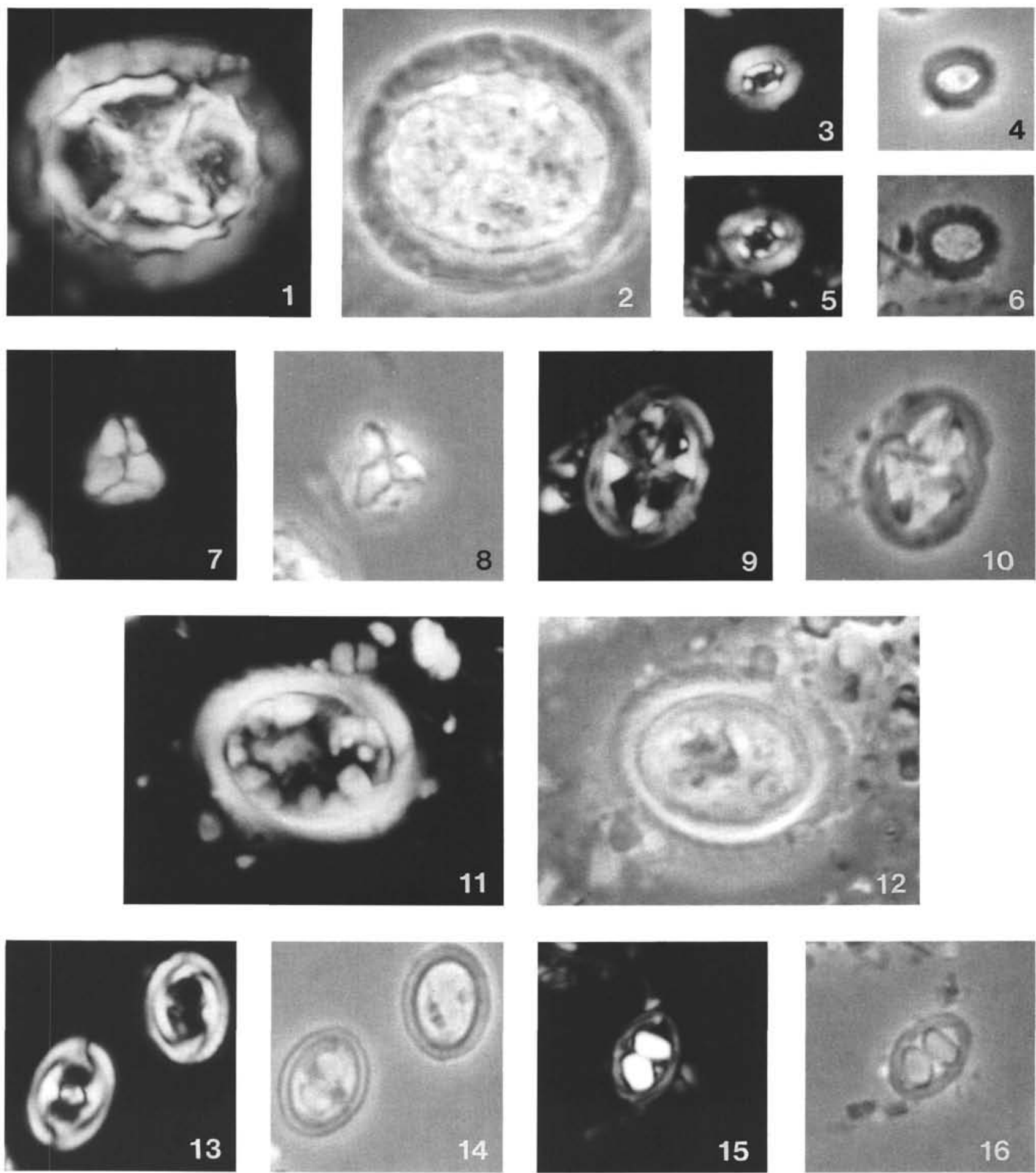

Plate 4. 1, 2. Prediscosphaera grandis, Sample 122-761C-3R-3, $10 \mathrm{~cm}$, (1) polarized, (2) phase contrast. 3, 4. P. stoveri, Sample 122-761C-3R-3, $68 \mathrm{~cm}$, central cross etched out, (3) polarized, (4) phase contrast. 5, 6. P. stoveri, Sample 122-761C-3R-3, $68 \mathrm{~cm}$, central cross slightly etched, (5) polarized, (6) phase contrast. 7, 8. Micula? sp., Sample 122-761C-3R-3, $140 \mathrm{~cm}$, (7) polarized, (8) phase contrast. 9, 10. Vagalapilla aachena, Sample $122-761 \mathrm{C}-3 \mathrm{R}-3,130 \mathrm{~cm}$, (9) polarized, (10) phase contrast. 11, 12. Zygodiscus sp., Sample 122-761C-3R-3, $10 \mathrm{~cm}$, (11) polarized, (12) phase contrast. 13, 14. Z. spiralis, Sample 122-761C-3R-3, $130 \mathrm{~cm}$, (13) polarized, (14) phase contrast. 15, 16. Tranolithus minimus, Sample 122-761C-3R-3, $140 \mathrm{~cm},(15)$ polarized, (16) phase contrast. Magnification for all figures is approximately $\times 3200$. 